Supporting Information

\title{
A Reversible Reaction Inside a Self-Assembled Capsule
}

Tetsuo Iwasawa, Enrique Mann, and Julius Rebek, Jr.*

The Skaggs Institute for Chemical Biology and the Department of Chemistry, The Scripps Research Institute MB-26, 10550 North Torrey Pines Road, La Jolla, California 92037

\section{Contents}

(1) General

(2) The temperature dependence of the encapsulated equilibrium between $6 \mathrm{~d}$ and 7d. (Figure 1S)

(3) Complete assignments of NMR spectra and $\Delta \delta$ between free and encapsulated species for $2 / 3$ and $4 / 5$ isomerizations.

-1) Preparation of 2/3 tautomers. (Scheme 1S)

-2) Assignments and $\Delta \delta$ between free and encapsulated species for $2 / 3$ isomerization (Figure 2S)

-3) Preparation of 4/5 tautomers.

-4) Assignments and $\Delta \delta$ between free and encapsulated species for $4 / 5$ isomerization (Figure 3S)

(4) Encapsulation experiments of 6b, 6c, 6d and 6e.

-1) Preparation of $6 b, 6 c, 6 d$ and $6 e$.

-2) Encapsulation of $6 b, 6 c, 6 d$ and $6 e$ with the cylindrical capsule. (Figure 4S 8S)

(5) Corroborative data of encapsulation experiments. (Figure 9S - 11S)

(6) References

(1) General NMR spectra were recorded on a Bruker DRX-600 spectrometer. Proton $\left({ }^{1} \mathrm{H}\right)$ chemical shifts, reported in parts per million (ppm), were indirectly referenced to external tetramethylsilane employing resonances due to trace protiated-solvent as an internal references. Abbreviations are as follows: s, singlet; $d$, doublet; t, triplet; m, multiplet; brs, broad singlet. Deuterated NMR solvents were obtained from Cambridge Isotope Laboratories, Inc., and used without further purification. All starting materials for preparing guests are purchased from Aldrich Chemical Company and were used without further purification. 
(2) The temperature dependence of the encapsulated equilibrium between $6 \mathrm{~d}$ and 7d.

The temperature dependence of the encapsulated equilibrium showed the equilibrium constant remained unchanged over nearly $100{ }^{\circ} \mathrm{C}$. The upfield portions of ${ }^{1} \mathrm{H}$ NMR spectra are shown in Figure 1S.

a)

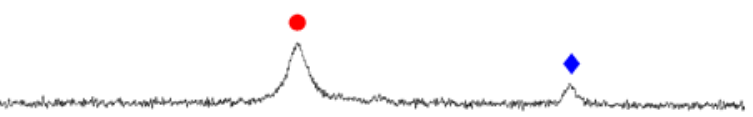

b)
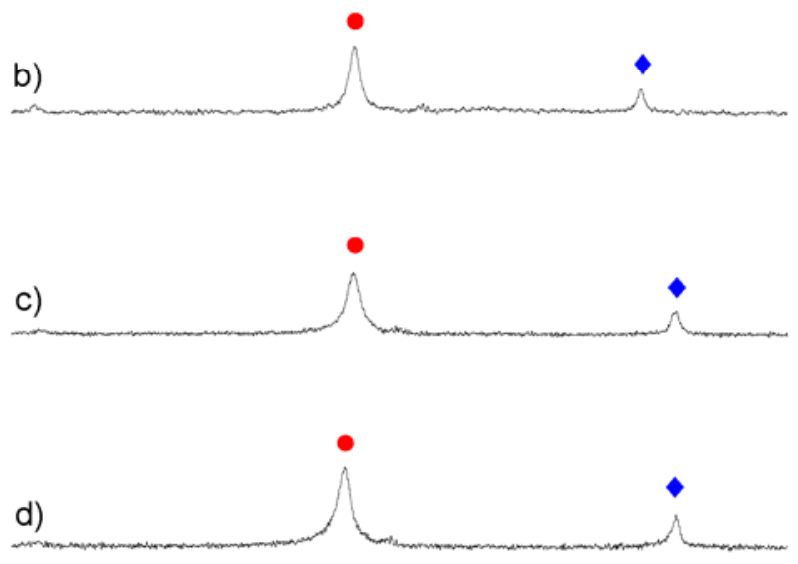

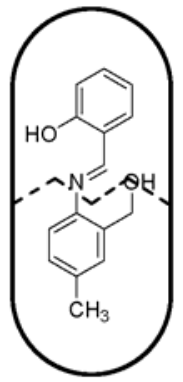

6d@1.1

$87 \%$

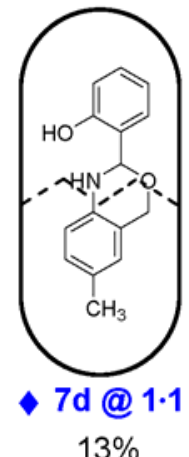

$13 \%$

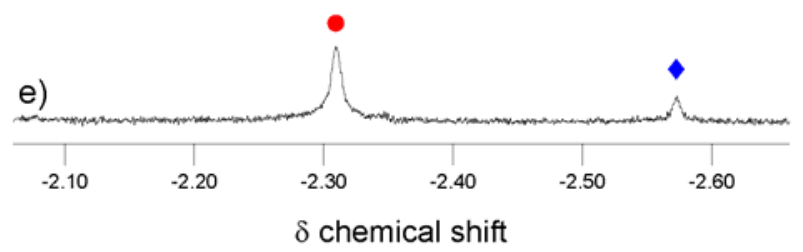

Figure 1S. Upfield portions of ${ }^{1} \mathrm{H}$ NMR spectra (600 MHz, mesitylene- $\mathrm{d}_{12}$ ) of $\mathbf{6 d} @ \mathbf{1 \cdot 1}$ and 7d@1·1 at various temperatures; a) $340 \mathrm{~K}$; b) $320 \mathrm{~K}$; c) $273 \mathrm{~K}$; d) $263 \mathrm{~K}$; e) $253 \mathrm{~K}$. These showed the equilibrium constant $(K=\mathbf{6 d} / \mathbf{7 d}=6.7)$ remained unchanged over nearly $100^{\circ} \mathrm{C}$. 
(3) Complete assignments of NMR spectra and $\Delta \delta$ between free and encapsulated species for $2 / 3$ and $4 / 5$ isomerizations.

-1) Preparation of 2/3 tautomers.

Scheme 1S. Synthesis of 2 and 3

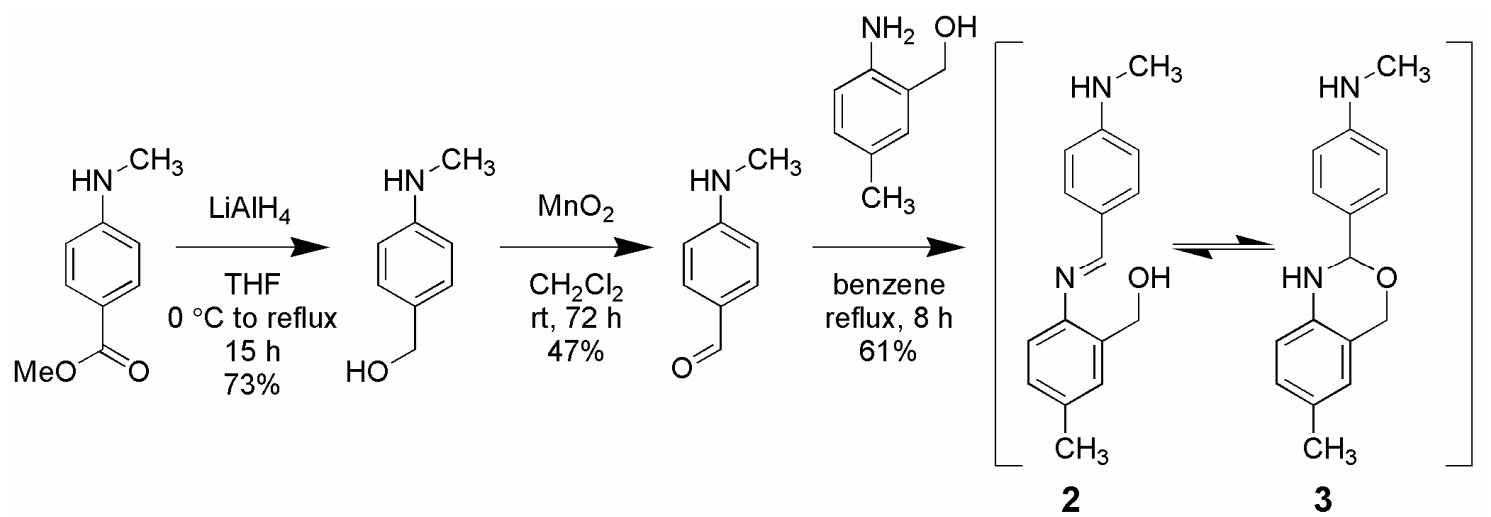

Commercially available methyl 4-(methylamino)benzoate (3.00 g, $18.6 \mathrm{mmol}$ ) was dissolved in THF $(100 \mathrm{~mL})$ and cooled under nitrogen to $0{ }^{\circ} \mathrm{C}$, and slowly $\mathrm{LiAlH}_{4}$ (1.41 g, $37.2 \mathrm{mmol}$ ) was added. After reflux for $15 \mathrm{~h}$, the reaction mixture was quenched by the sequential slow addition of $3 \mathrm{~mL}$ of water, $3 \mathrm{~mL}$ of $10 \%$ aqueous $\mathrm{NaOH}$, and $3 \mathrm{~mL}$ of water. The reaction was stirred for $0.5 \mathrm{~h}$, and filtered. The solvent was removed in vacuo, and the crude products were taken up in $\mathrm{CH}_{2} \mathrm{Cl}_{2}$ and dried over $\mathrm{MgSO}_{4}$. The drying agent was removed by filtration, and the filtrate was concentrated under reduced pressure. Purification of the residue by column chromatography $\left(\mathrm{SiO}_{2}, \quad 1: 1 \quad\right.$ hexane-ethyl acetate eluent $)$ afforded 4-(methylamino)phenyl)methanol (1.86 g, 73\%) as a pale yellow solid material. The data of NMR and MS were identical to those previously reported in the literature ${ }^{1}$.

To a solution of (4-(methylamino)phenyl)methanol (1.00 g, $7.3 \mathrm{mmol})$ in $\mathrm{CH}_{2} \mathrm{Cl}_{2}(50 \mathrm{~mL})$ was added $\mathrm{MnO}_{2}(2.60 \mathrm{~g}, 30 \mathrm{mmol})$. The mixture was stirred at room temperature for $24 \mathrm{~h}$, and then more $\mathrm{MnO}_{2}$ (2.6 g, $\left.30 \mathrm{mmol}\right)$ was added. After additional stirring for $48 \mathrm{~h}$, the mixture was filtered through celite, and concentrated in vacuo. The residue was purified by column chromatography $\left(\mathrm{SiO}_{2}, 2: 3\right.$ ethyl acetate-hexane eluent) to give (4-(methylamino)benzaldehyde (463 $\mathrm{mg}, 47 \%$ ) as a red oil which crystallized after one week $4{ }^{\circ} \mathrm{C}$. The data of NMR and MS were identical to those previously reported in the literature ${ }^{2}$.

The reaction between 4-(methylamino)benzaldehyde (463 mg, $3.4 \mathrm{mmol}$ ) and (5-methyl-2-(methylamino)phenyl)methanol (559 mg, $4.1 \mathrm{mmol}$ ) in refluxing benzene (7 mL) with Dean-Stark apparatus and the following recrystallization produced desired 
compounds in $61 \%$ yield (532 $\mathrm{mg}$ ) as pale yellow crystals.

2 and 3: The tautomerism between 2 and 3 in mesitylene- $d_{12}$ plateau with 34:66 ratio. The ${ }^{1} \mathrm{H}$ NMR spectrum is shown below. ${ }^{1} \mathrm{H}$ NMR (600 MHz, $300 \mathrm{~K}$, mesitylene- $\left.d_{12}\right) \delta$ (for 3) 7.31 (d, $J=8.4 \mathrm{~Hz}, 2 \mathrm{H}$ ), 6.74 (d, $J=8.4 \mathrm{~Hz}, 1 \mathrm{H}$ ), 6.43 (brs, 1H), 6.31 (d, $J=8.4$ Hz, 1H), 6.28 (d, $J=8.4 \mathrm{~Hz}, 2 \mathrm{H}), 5.22$ (d, $J=6.0 \mathrm{~Hz}, 1 \mathrm{H}), 4.78$ (d, $J=14.4 \mathrm{~Hz}, 1 \mathrm{H}$ ), 4.66 (d, $J=14.4 \mathrm{~Hz}, 1 \mathrm{H}$ ), 3.37 (d, $J=6.0 \mathrm{~Hz}, 1 \mathrm{H}$ ), 2.85 (brs, 1H), 2.34 (s, 3H), 2.14 (s, 3H), $\delta$ (for 2) 8.05 (s, 1H), 7.55 (d, $J=8.4 \mathrm{~Hz}, 2 \mathrm{H}$ ), 6.90 (d, $J=8.4 \mathrm{~Hz}, 1 \mathrm{H}$ ), 6.88 (s, 1H), 6.79 (d, $J=8.4 \mathrm{~Hz}, 1 \mathrm{H}$ ), 6.15 (d, $J=8.4 \mathrm{~Hz}, 2 \mathrm{H}$ ), 4.79 (s, 2H), 4.05 (brs, 1H), 3.05 (brs, 1H), 2.31 (s, 3H), 2.19 (s, 3H). ${ }^{13} \mathrm{C} \mathrm{NMR}\left(150 \mathrm{MHz}, \mathrm{CDCl}_{3}\right) \delta$ (for 3) 149.9, 139.5, 128.9, 127.9, 127.5, 125.2, 124.9, 122.3, 112.1, 85.5, 67.7, 30.6, 20.6, $\delta$ (for 2) 158.4, 152.1, 147.6, 135.2, 134.7, 130.7, 128.8, 128.6, 127.9, 117.1, 111.8, 64.7, 30.1, 20.9. HRMS (ESI, $\mathrm{MH}^{+}$): Calcd. For $\mathrm{C}_{16} \mathrm{H}_{19} \mathrm{~N}_{2} \mathrm{O}$ : 255.1492. Found: 255.1503.

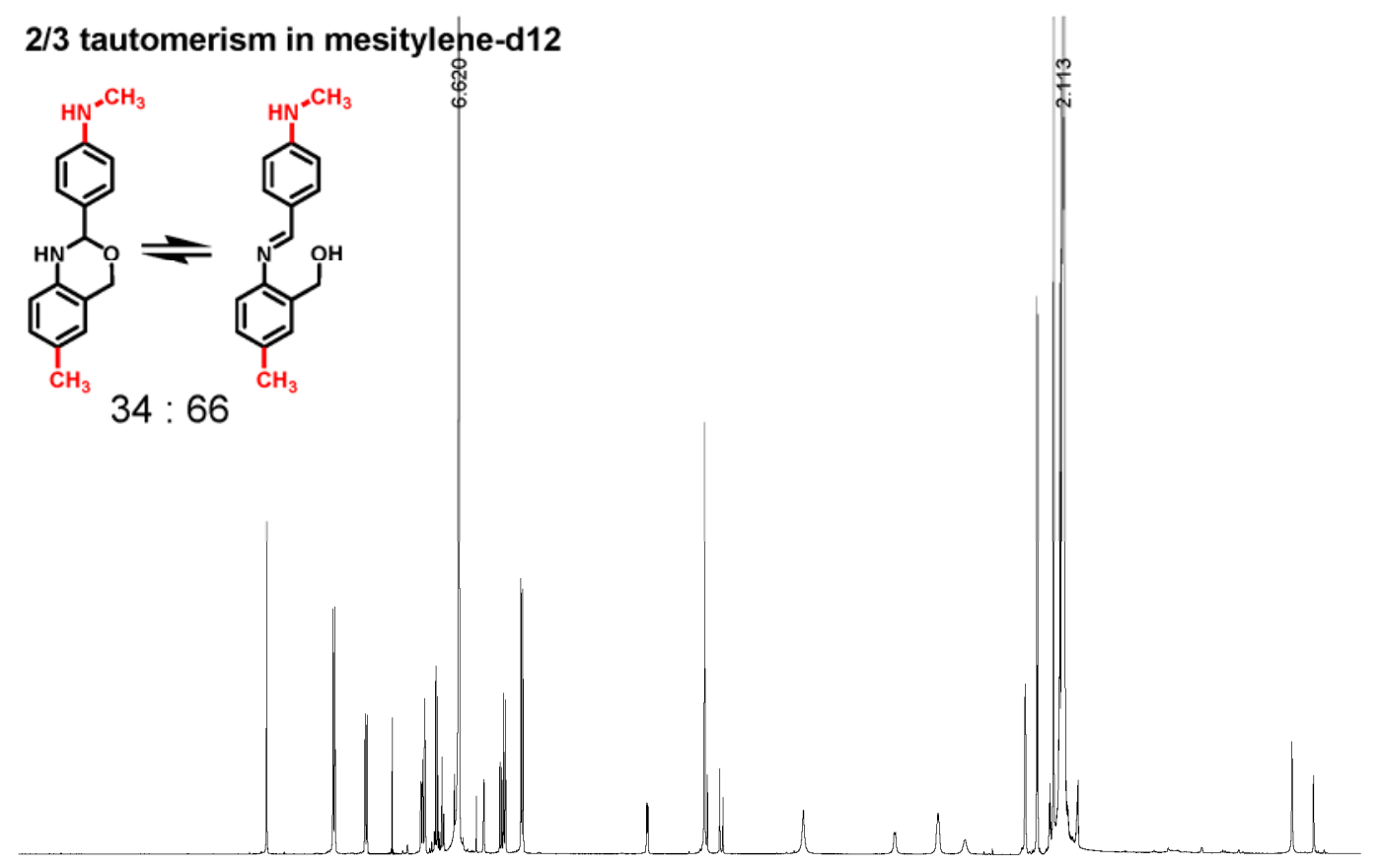

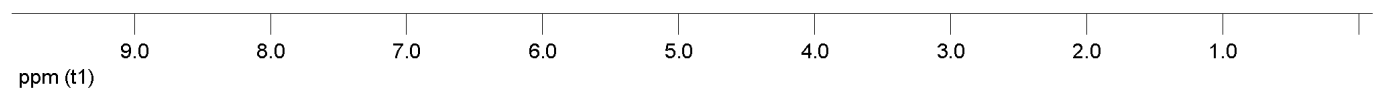


3-2) Assignments and $\Delta \delta$ between free and encapsulated species for $2 / 3$ isomerization

a)
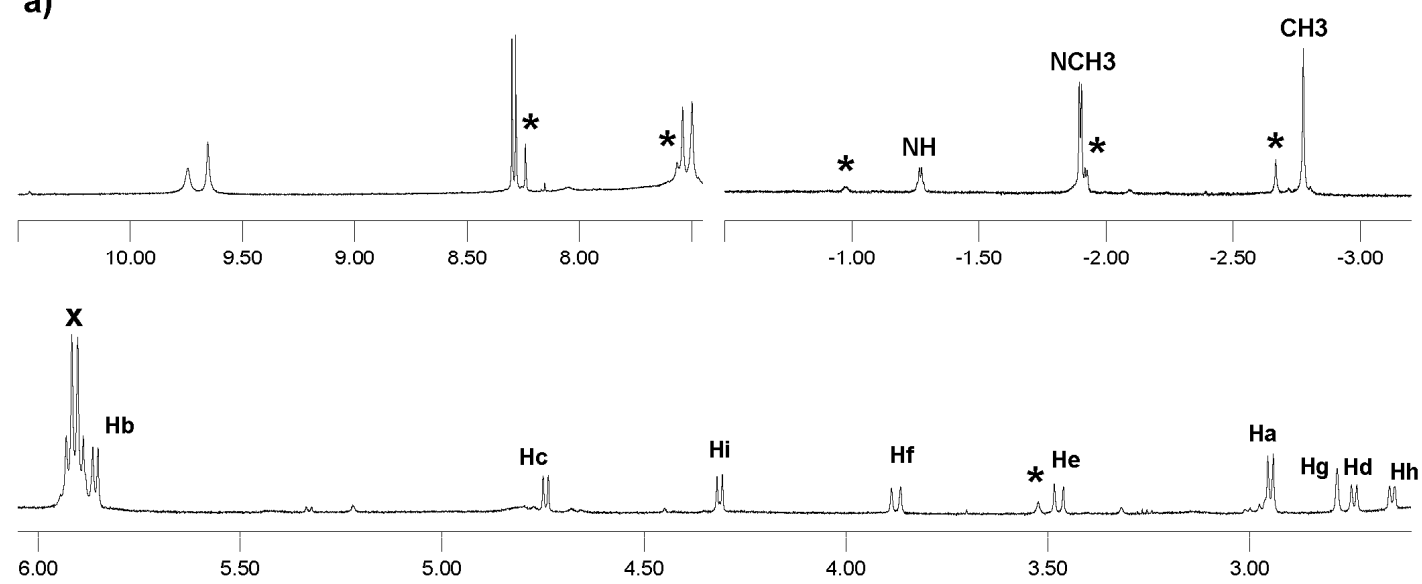

b) $\quad \mathrm{CH}_{3} \cdots-\delta-1.90(\mathrm{~d}, J=5.4 \mathrm{~Hz}, \Delta \delta=4.24)$

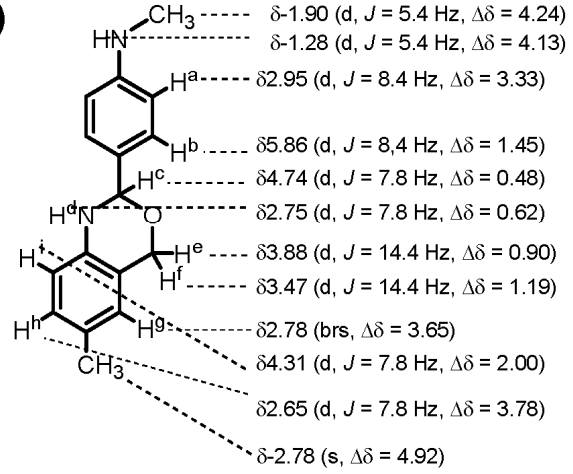

Figure 2S. Encapsulation experiments of 2 and 3. (a) Downfield, mid-field, and upfield portions of ${ }^{1} \mathrm{H}$ NMR spectra (600 MHz, $300 \mathrm{~K}$, mesitylene- $\left.d_{12}\right)$ of 2@1·1 and 3@1·1. The peaks labeled with asterisks were estimated to be a detectable amount of 2@1·1. The peaks in downfield portions are corresponding to those of asymmetrically filled capsule, $\delta$ (for 3@1·1) 9.76 (s, 4H, NH), 9.74 (s, 4H, NH), 8.30 (s, 4H, arom), 8.28 (s, 4H, arom), 7.54 (s, 4H, arom), 7.50 (s, 4H, arom). Other signals of 3@1·1 in portions of mid-field and upfield are assigned as shown in (b) with $\Delta \delta$ values between free and encapsulated species. The peaks labeled $\mathrm{x}$ are $\mathrm{CH}$-methines of $\mathbf{1 \cdot 1}$. 


\section{3-3) Preparation of 4/5 tautomers.}

The 4/5 tautomers were prepared according to literature procedure. ${ }^{3}$ The $4 / 5$ tautomerism in mesitylene- $d_{12}$ plateau with 61:39 ratio. The ${ }^{1} \mathrm{H}$ NMR spectrum is shown below. ${ }^{1} \mathrm{H}$ NMR (600 MHz, $300 \mathrm{~K}$, mesitylene- $d_{12}$ ) $\delta$ (for 5) 7.35 (d, $J=8.4 \mathrm{~Hz}$, 2H), 7.09 (m, 1H), 6.93 (m, 1H), 6.67 (m, 1H), 6.51 (d, $J=8.4 \mathrm{~Hz}, 2 \mathrm{H}), 6.35$ (d, $J=8.4$ $\mathrm{Hz}, 1 \mathrm{H}), 5.24$ (d, $J=5.4 \mathrm{~Hz}, 1 \mathrm{H}), 4.78$ (d, $J=14.4 \mathrm{~Hz}, 1 \mathrm{H}), 4.67$ (d, $J=14.4 \mathrm{~Hz}, 1 \mathrm{H})$, 3.49 (d, $J=5.4 \mathrm{~Hz}, 1 \mathrm{H}$ ), 2.57 (s, 6H), $\delta$ (for 4) 8.04 (s, 1H), 7.61 (d, $J=9.0 \mathrm{~Hz}, 2 \mathrm{H}$ ), 7.07 (m, 1H), 6.98 (m, 1H), 6.81 (m, 1H), 6.50 (d, $J=8.4 \mathrm{~Hz}, 1 \mathrm{H}), 6.33$ (d, $J=9.0 \mathrm{~Hz}$, 2H), 4.80 (d, $J=4.8 \mathrm{~Hz}, 2 \mathrm{H}), 3.87$ (t, $J=4.8 \mathrm{~Hz}, 1 \mathrm{H}), 2.50$ (s, 6H). ${ }^{13} \mathrm{C}$ NMR (150 $\mathrm{MHz}, \mathrm{CDCl}_{3}$ ) $\delta$ (for 5) 151.0, 142.0, 127.4, 127.2, 126.9, 124.8, 121.8, 119.1, 116.4, 112.2, 85.2, 67.7, $40.4 \delta$ (for 4) 159.2, 152.7, 150.3, 134.9, 130.6, 128.3, 127.8, 125.3, 123.7, 117.3, 111.5, 64.5, 40.0. HRMS (ESI, $\mathrm{MH}^{+}$): Calcd. For $\mathrm{C}_{16} \mathrm{H}_{19} \mathrm{~N}_{2} \mathrm{O}$ : 255.1492. Found: 255.1498.

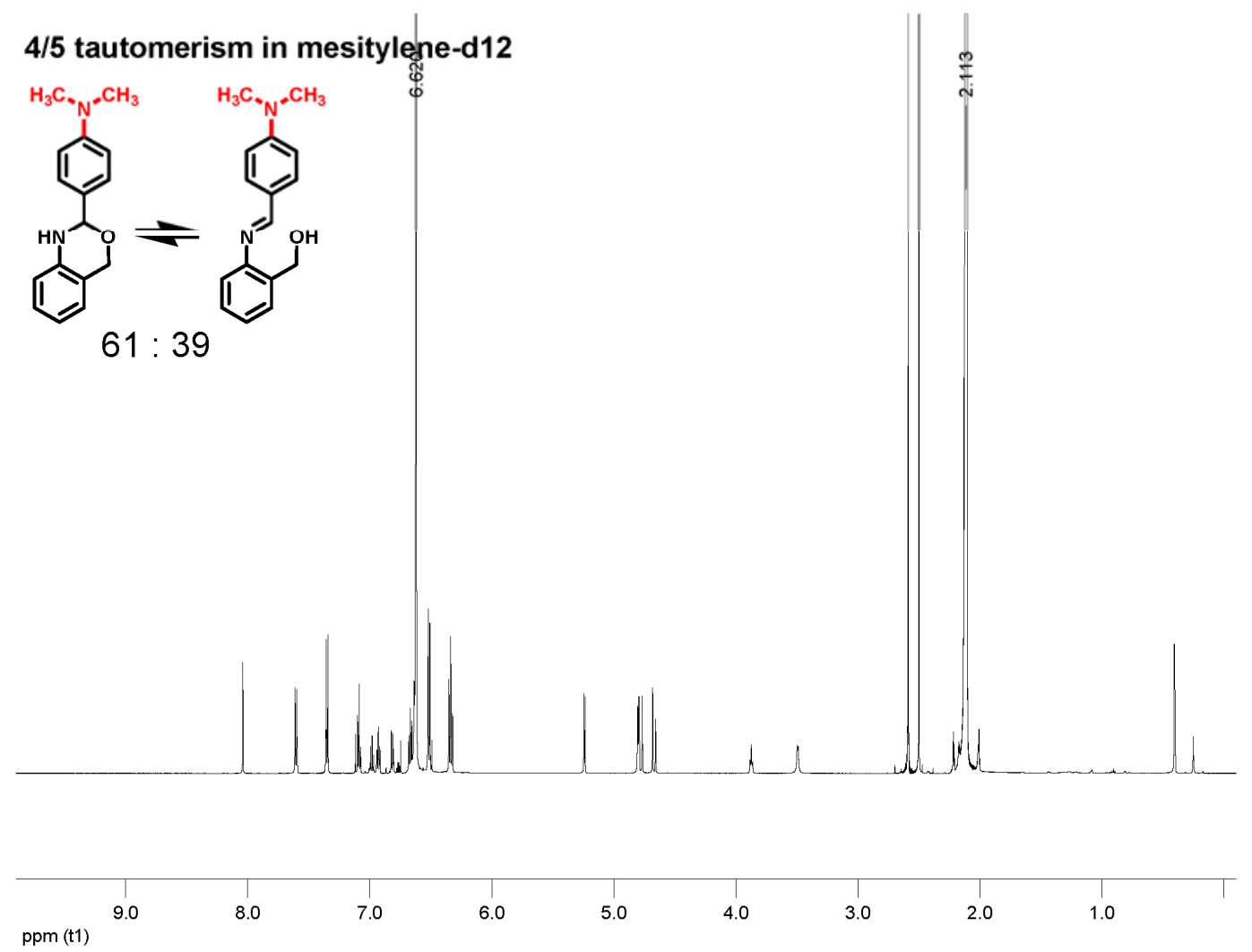




\section{3-4) Assignments and $\Delta \delta$ between free and encapsulated species for $4 / 5$ isomerization}

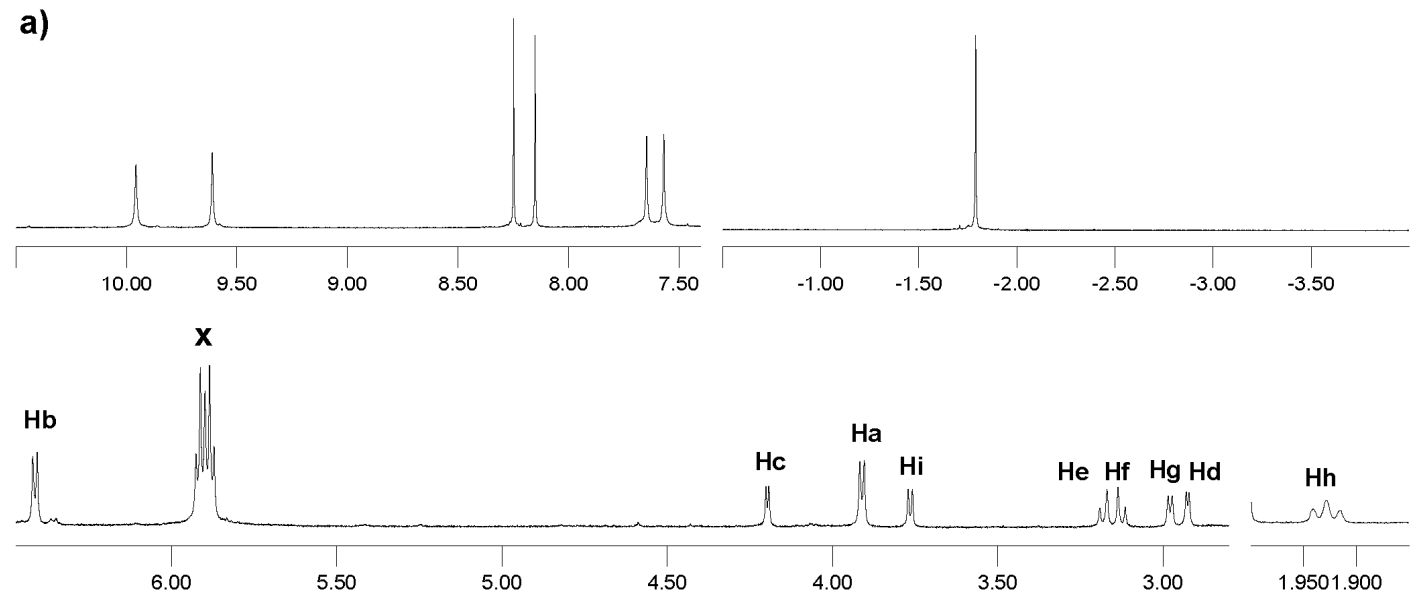

b) $\mathrm{H}_{3} \mathrm{C}_{N_{N}}-\mathrm{CH}_{3}-\cdots-1.79(\mathrm{~s}, \Delta \delta=4.36)$

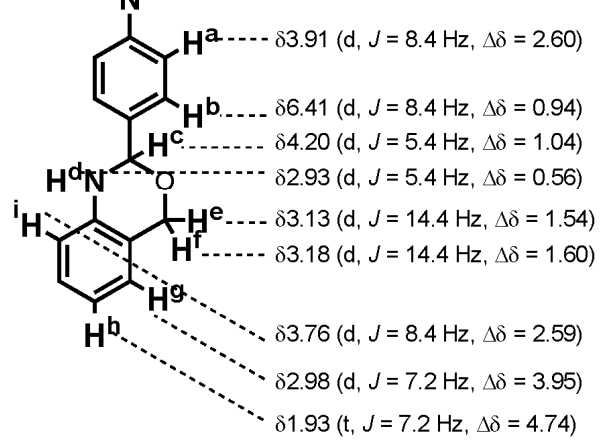

Figure 3S. Encapsulation experiments of 4 and 5. (a) Downfield, mid-field, and upfield portions of ${ }^{1} \mathrm{H}$ NMR spectra $\left(600 \mathrm{MHz}, 300 \mathrm{~K}\right.$, mesitylene- $\left.d_{12}\right)$ of $\mathbf{5} @ \mathbf{1 \cdot 1}$. A detectable amount of 4@1·1 was not formed. The peaks in downfield portions are corresponding to those of asymmetrically filled capsule, $\delta 9.96$ (s, 4H, NH), 9.61 (s, 4H, NH), $8.24(\mathrm{~s}, 4 \mathrm{H}$, arom), 8.15 (s, 4H, arom), 7.65 (s, 4H, arom), 7.57 (s, 4H, arom). Other signals of 5@1.1 in portions of mid-field and upfield are assigned as shown in (b) with $\Delta \delta$ values between free and encapsulated species. However, the peak of $\mathrm{H}_{\mathrm{i}}$ overlapped with peaks of solvent or $\mathbf{1 \cdot 1}$. The peaks labeled $\mathrm{x}$ are $\mathrm{CH}$-methines of $\mathbf{1 \cdot 1}$. 
(4) Encapsulation experiments of 6b, 6c, 6d and $6 e$.

-1) Preparation of 6b, 6c, $6 d$ and $6 e$.

Schiff's bases $\mathbf{6 b}, \mathbf{6 c}, \mathbf{6} \mathbf{d}^{4}$ and $\mathbf{6} \mathbf{e}^{5}$ were prepared from corresponding aldehydes and anilines through conventional condensation methods. The physical data of them are shown below, as well as ${ }^{1} \mathrm{H}$ NMR spectra in mesitylene- $d_{12}$.

6b: ${ }^{1} \mathrm{H}$ NMR (600 MHz, $300 \mathrm{~K}$, mesitylene- $d_{12}$ ) $\delta 13.1$ (s, 1H), 8.02 (s, 1H), 7.20 (s, 1H), 6.88 (d, $J=8.4 \mathrm{~Hz}, 1 \mathrm{H}), 6.86$ (d, $J=7.8 \mathrm{~Hz}, 1 \mathrm{H}), 6.78$ (s, 1H), 6.65 (d, $J=7.8 \mathrm{~Hz}$, 1H), 6.52 (d, $J=8.4 \mathrm{~Hz}, 1 \mathrm{H}$ ), 4.52 (d, $J=5.4 \mathrm{~Hz}, 2 \mathrm{H}$ ), 2.20 (s, 3H), 2.10 (s, 3H), 0.87 (brs, $1 \mathrm{H}) . \quad{ }^{13} \mathrm{C}$ NMR $\left(150 \mathrm{MHz}, \mathrm{CDCl}_{3}\right) \delta 161.9,161.0,144.4,144.1,136.8,134.3$, 132.0, 129.2, 129.0, 120.3, 117.6, 117.5, 117.0, 61.9, 21.9, 21.0. HRMS (ESI, $\mathrm{MNa}^{+}$): Calcd. For $\mathrm{C}_{16} \mathrm{H}_{17} \mathrm{NO}_{2} \mathrm{Na}$ : 278.1151. Found: 278.1145.

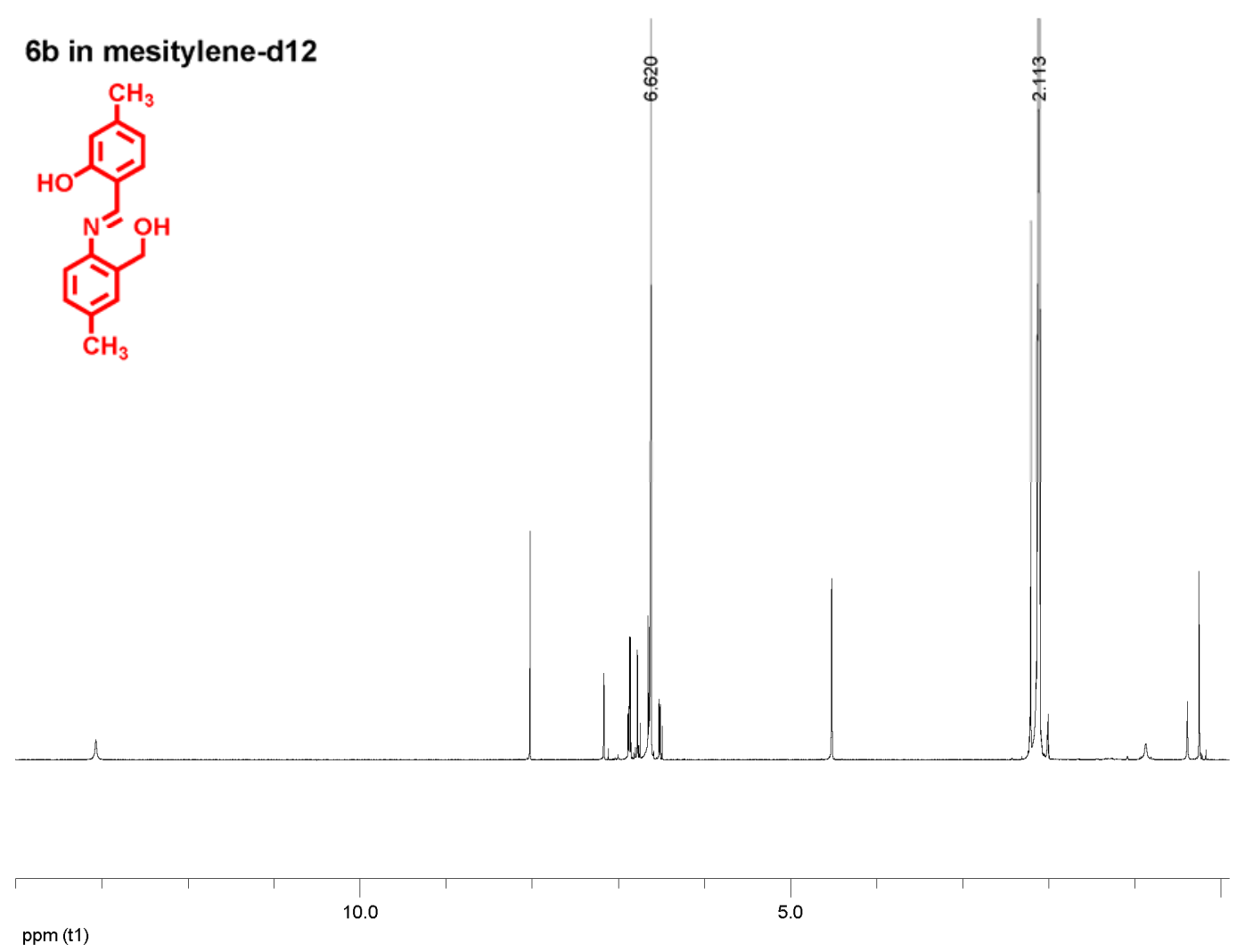


6c: ${ }^{1} \mathrm{H}$ NMR (600 MHz, $300 \mathrm{~K}$, mesitylene- $d_{12}$ ) $\delta 12.9$ (s, 1H), 7.94 (s, 1H), 7.35 (m, $1 \mathrm{H}), 7.06-7.04$ (m, 2H), 6.86 (d, $J=7.8 \mathrm{~Hz}, 1 \mathrm{H}), 6.77$ (s, 1H), 6.65 (m, 1H), 6.51 (d, $J=$ $7.8 \mathrm{~Hz}, 1 \mathrm{H}), 4.49$ (d, $J=4.2 \mathrm{~Hz}, 2 \mathrm{H}), 2.09$ (s, 3H), 0.86 (brs, 1H). ${ }^{13} \mathrm{C}$ NMR (150 MHz, $\left.\mathrm{CDCl}_{3}\right) \delta 162.6,161.0,146.5,144.5,134.4,132.1,128.6,128.1,126.7,120.3,117.8$, 117.5, 116.9, 61.6, 21.8. HRMS (ESI, $\mathrm{MH}^{+}$): Calcd. For $\mathrm{C}_{15} \mathrm{H}_{16} \mathrm{NO}_{2}$ : 242.1175. Found: 242.1176.

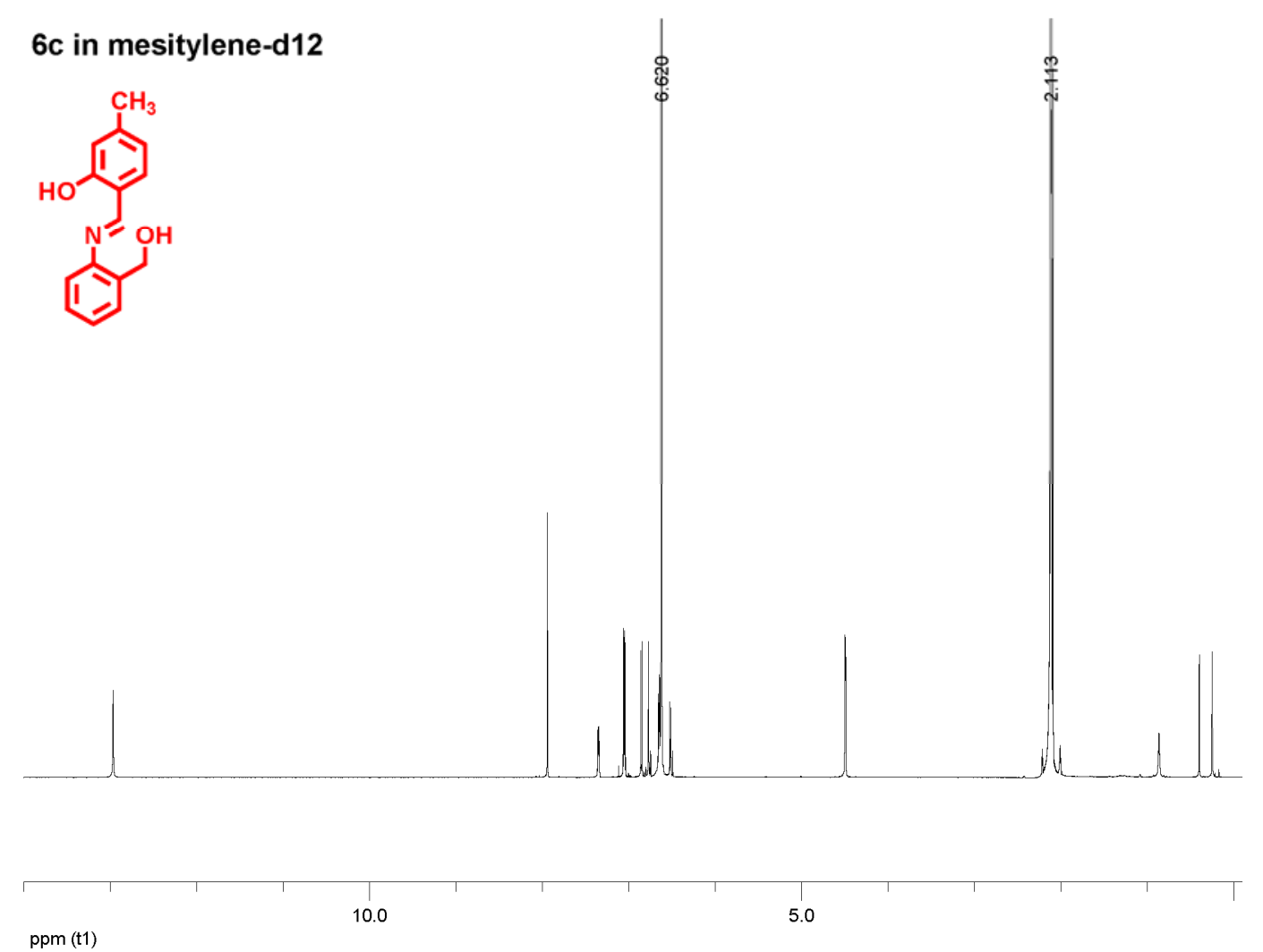

ppm (t1) 
6d: ${ }^{1} \mathrm{H}$ NMR (600 MHz, $300 \mathrm{~K}$, mesitylene- $\left.d_{12}\right) \delta 13.1$ (s, 1H), $8.00(\mathrm{~s}, 1 \mathrm{H}), 7.17$ (s, 1H), 7.07 (m, 1H), $6.96(\mathrm{~m}, 1 \mathrm{H}), 6.91(\mathrm{~m}, 1 \mathrm{H}), 6.88(\mathrm{~m}, 1 \mathrm{H}), 6.68(\mathrm{~m}, 1 \mathrm{H}), 6.64(\mathrm{~m}$, 1H), 4.50 (s, 2H), 2.20 (s, 3H), 0.87 (brs, 1H). $\left.{ }^{13} \mathrm{C} \mathrm{NMR} \mathrm{(150} \mathrm{MHz,} \mathrm{CDCl}_{3}\right) \delta 162.1$, 161.0, 143.9, 137.1, 134.4, 133.1, 132.2, 129.2, 129.0, 119.2, 119.0, 117.5, 117.2, 61.8, 21.0. HRMS (ESI, $\mathrm{MH}^{+}$): Calcd. For $\mathrm{C}_{15} \mathrm{H}_{16} \mathrm{NO}_{2}$ : 242.1175. Found: 242.1182 .

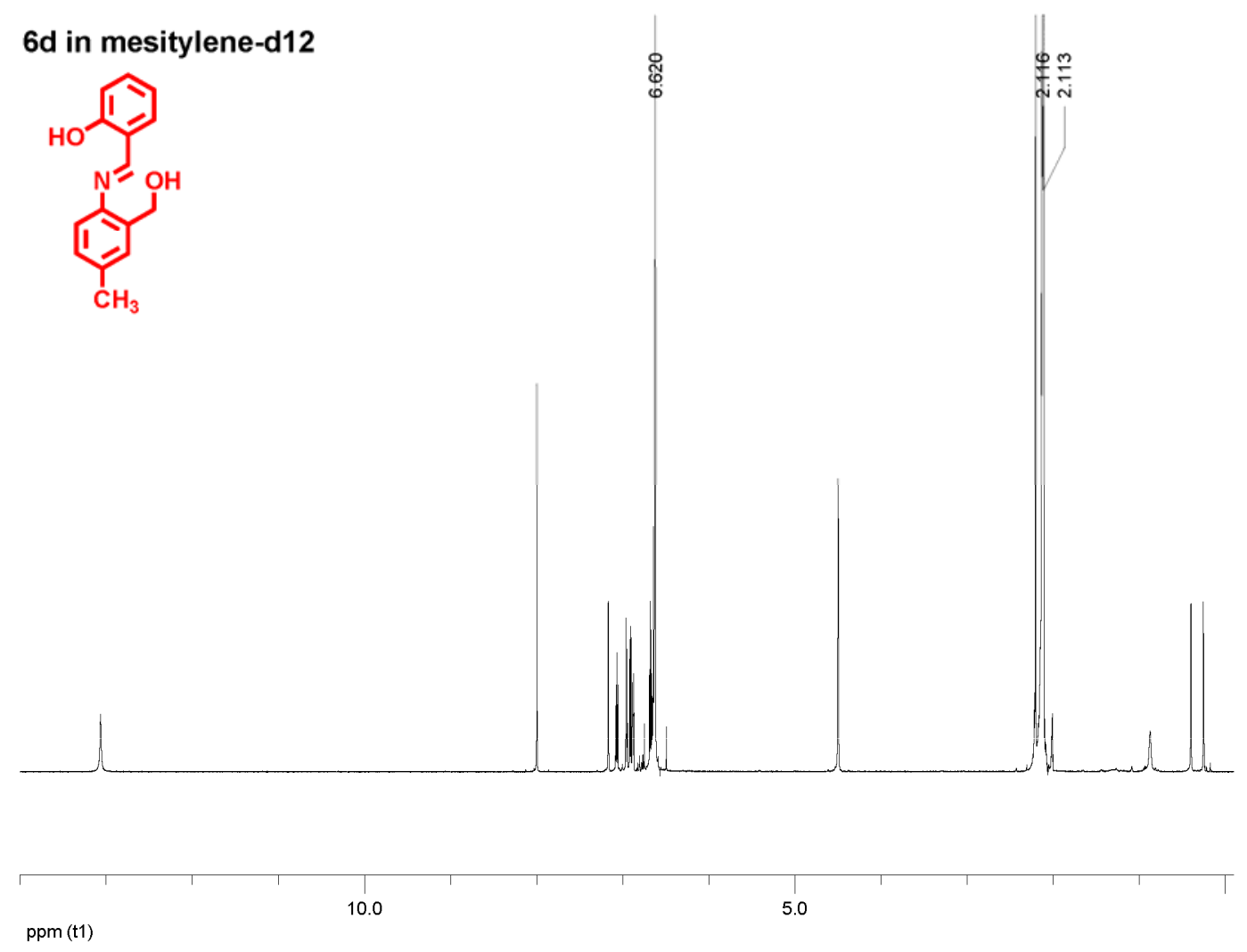


6e: ${ }^{1} \mathrm{H}$ NMR (600 MHz, $300 \mathrm{~K}$, mesitylene- $\left.d_{12}\right) \delta 13.5$ (s, 1H), 7.92 (s, 1H), 7.35 (m, 1H), 7.07-7.05 (m, 2H), 6.82 (d, $J=8.4 \mathrm{~Hz}, 1 \mathrm{H}), 6.68$ (m, 1H), 6.42 (d, $J=3.0 \mathrm{~Hz}, 1 \mathrm{H}$ ), 6.35 (dd, $J=8.4 \mathrm{~Hz}, 3.0 \mathrm{~Hz}, 1 \mathrm{H}$ ), 4.53 (d, $J=3.6 \mathrm{~Hz}, 2 \mathrm{H}$ ), 3.28 (s, 3H), 0.94 (t, $J=3.6$ $\mathrm{Hz}, 1 \mathrm{H}) .{ }^{13} \mathrm{C}$ NMR $\left(150 \mathrm{MHz}, \mathrm{CDCl}_{3}\right) \delta 164.4,164.2,161.4,145.9,134.2,133.6,128.6$, 128.2, 126.4, 117.7, 113.0, 107.2, 101.0, 61.6, 55.3. HRMS (ESI, $\mathrm{MH}^{+}$): Calcd. For $\mathrm{C}_{15} \mathrm{H}_{16} \mathrm{NO}_{3}$ : 258.1125. Found: 258.1126.

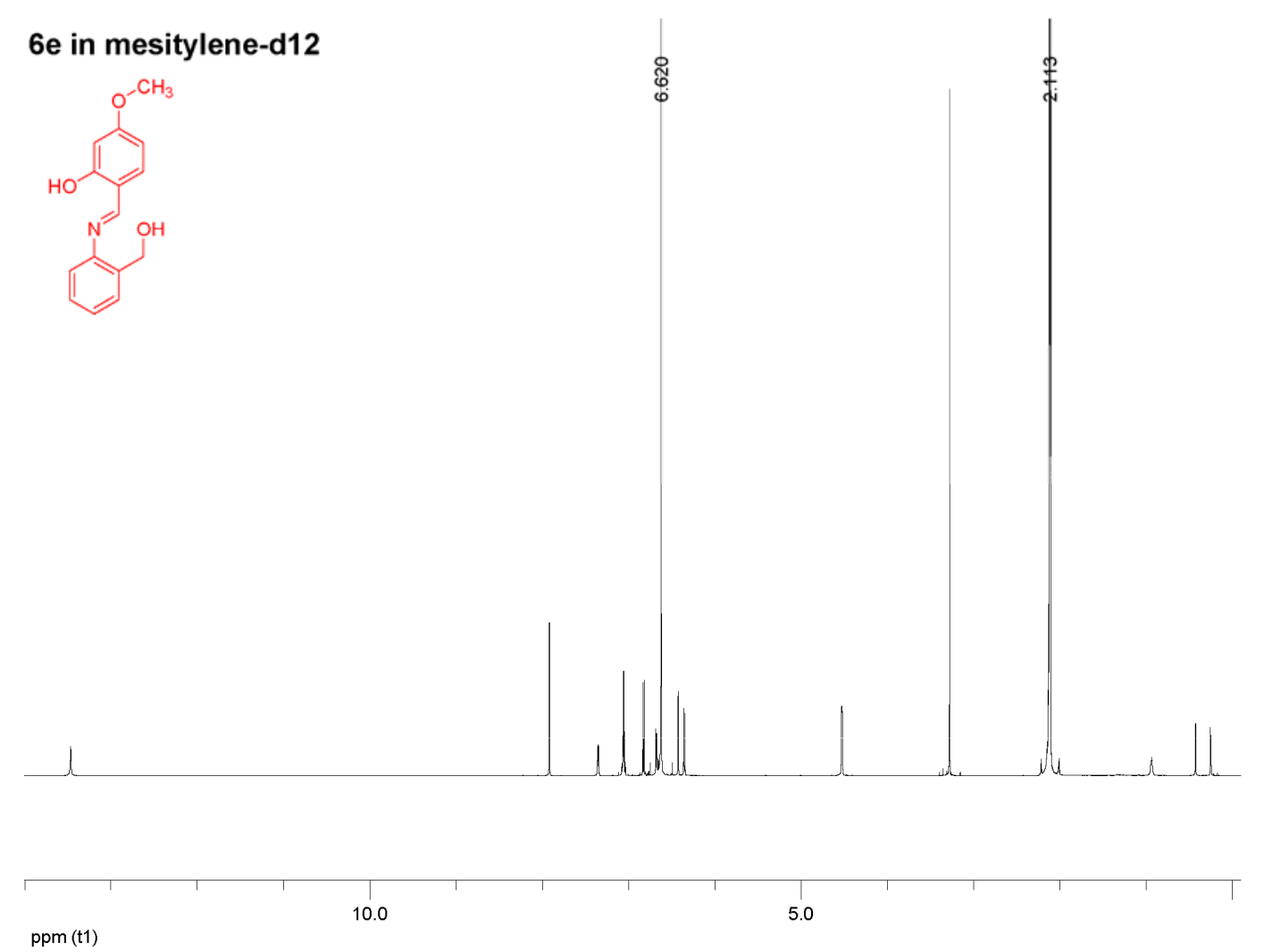


4-2) Encapsulation of $6 b, 6 c, 6 d$ and $6 e$ with the cylindrical capsule.

Encapsulation experiments of non-tautomeric Schiff's bases $\mathbf{6 b}-\mathbf{6 e}$ were carried out, which summarize in Figure 4S. ${ }^{1} \mathrm{H}$ NMR spectra $(600 \mathrm{MHz}, 300 \mathrm{~K}$, mesitylene- $d_{12}$ ) are shown in Figure 5S - 8S.

(a)
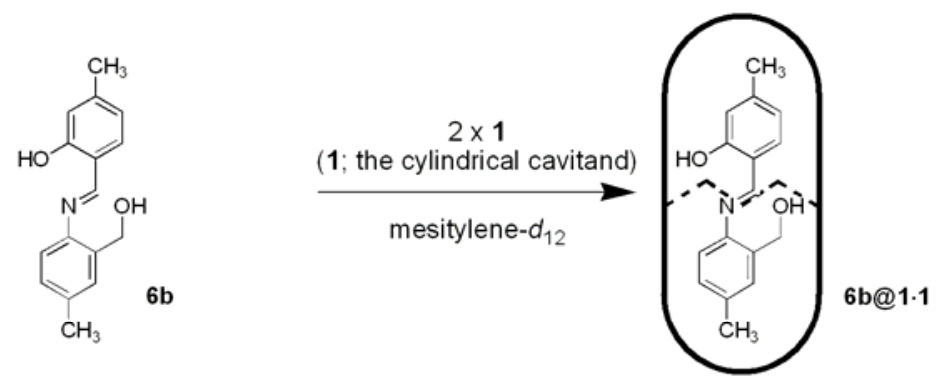

(b)
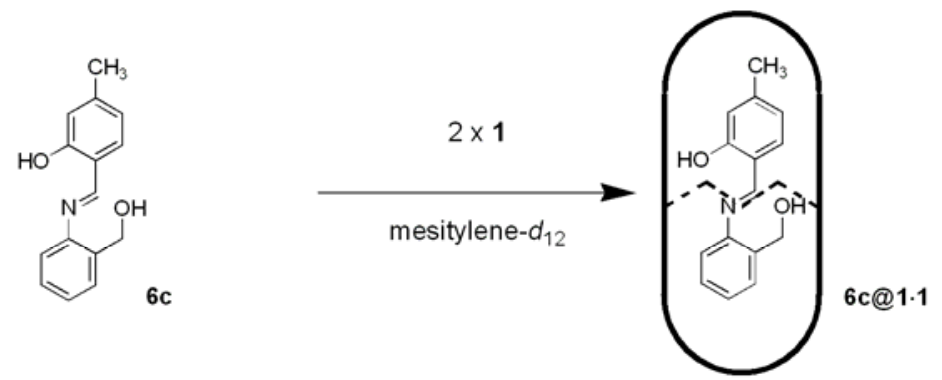

(c)
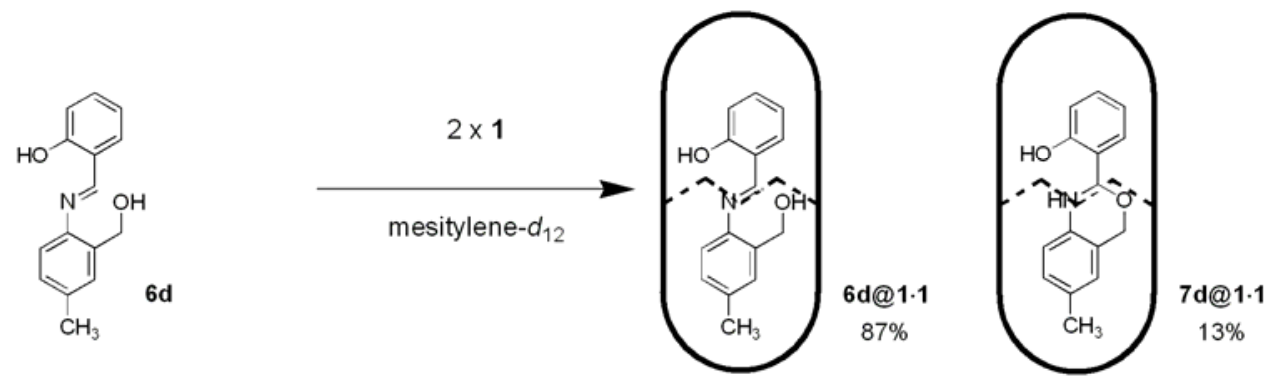

(d)
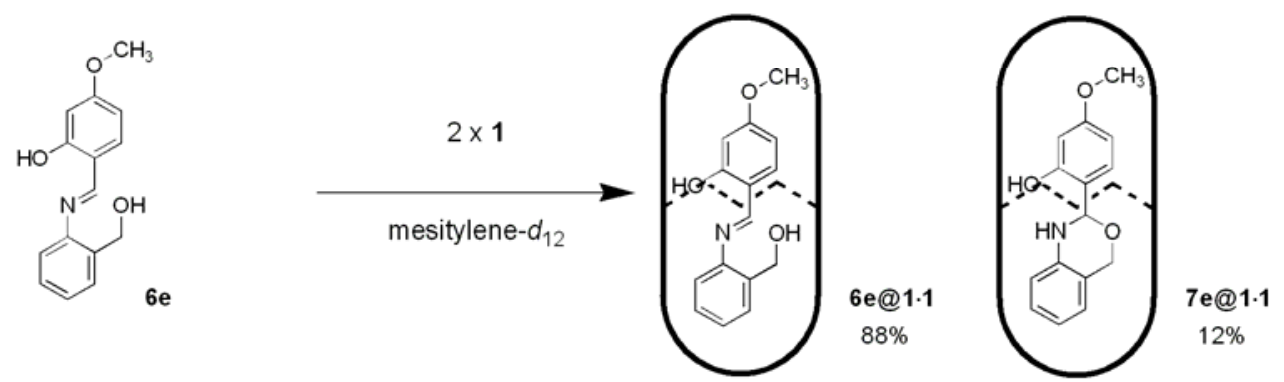

Figure 4S. Encapsulations of $\mathbf{6 b}-\mathbf{6 e}$ with $\mathbf{1 \cdot 1}$. They were carried out with the guest (excess over $\left.2.70 \times 10^{-3} \mathrm{mmol}\right)$ and 1 (10 mg, $5.94 \times 10^{-3}$ mmol) in mesitylene- $d_{12}(1.5$ mL).; a) 6b@1·1 was observed in >99\% ratio; b) 6c@1·1 was observed in >99\% ratio; c) a detectable amount of 7d@1·1 was observed in 13\% ratio; d) a detectable amount of 7e@1·1 was observed in 12\% ratio. 
a)
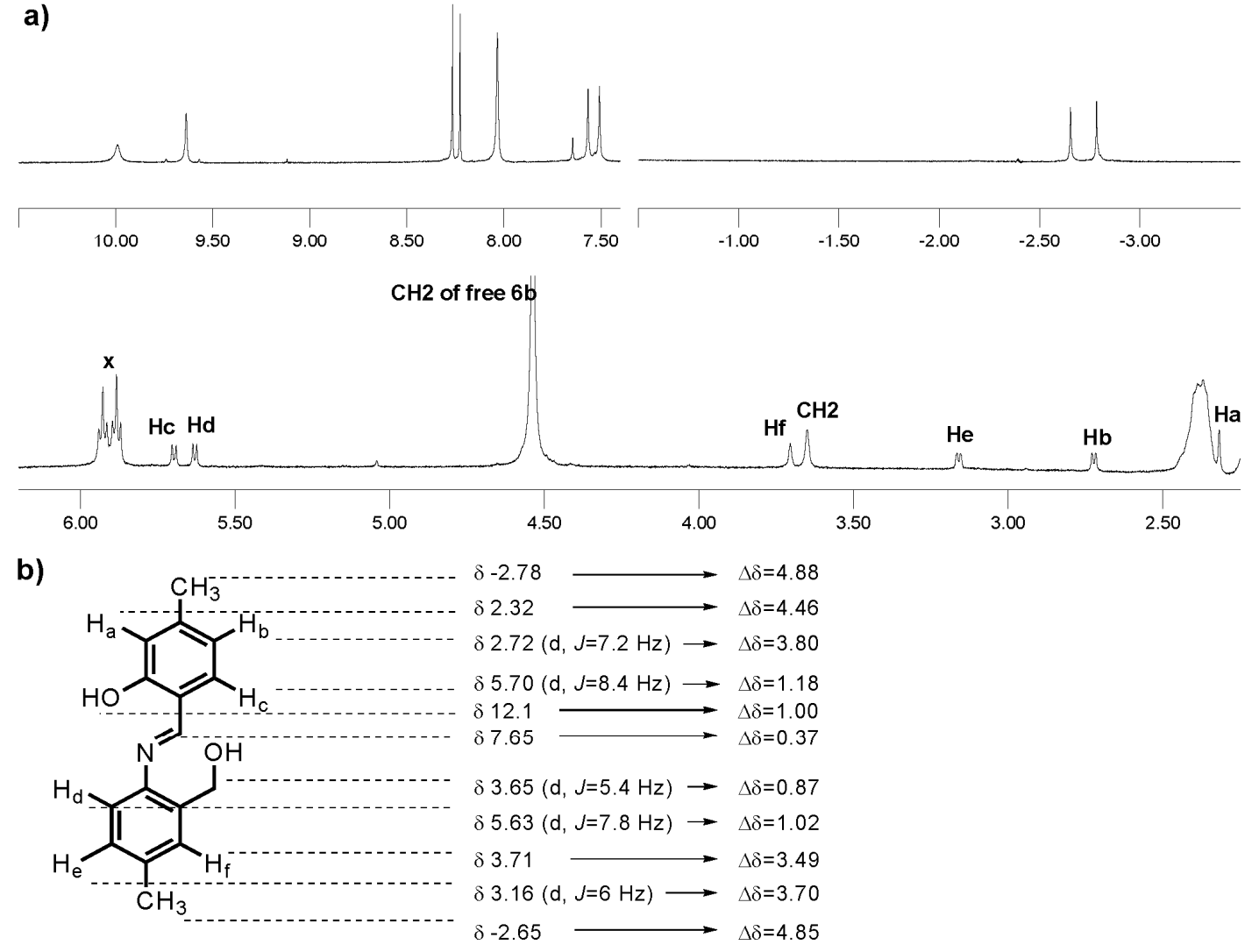

Figure 5S. Encapsulation experiments of 6b. (a) Downfield, mid-field, and upfield portions of ${ }^{1} \mathrm{H}$ NMR spectra (600 MHz, $300 \mathrm{~K}$, mesitylene- $\left.d_{12}\right)$ of $\mathbf{6 b} @ \mathbf{1} \cdot \mathbf{1}$ and free $\mathbf{6 b}$. Downfield portions of ${ }^{1} \mathrm{H}$ NMR; $\delta 9.99$ (s, 4H, NH), 9.64 (s, 4H, NH), 8.27 (s, 4H, arom), 8.23 (s, 4H, arom), 8.03 (s, $1 \mathrm{H}, \mathrm{N}=\mathrm{CH}$ of free $\mathbf{6 b}$ ), 7.67 (s, $1 \mathrm{H}, \mathrm{N}=\mathrm{CH}$ of 6b@1-1) 7.57 (s, 4H, arom), 7.51 (s, 4H, arom). Other signals in portions of mid-field and upfield are assigned as shown in (b) with $\Delta \delta$ values between free and encapsulated 6b. The peaks labeled $x$ are $\mathrm{CH}$-methines of the cylindrical capsule. 
a)
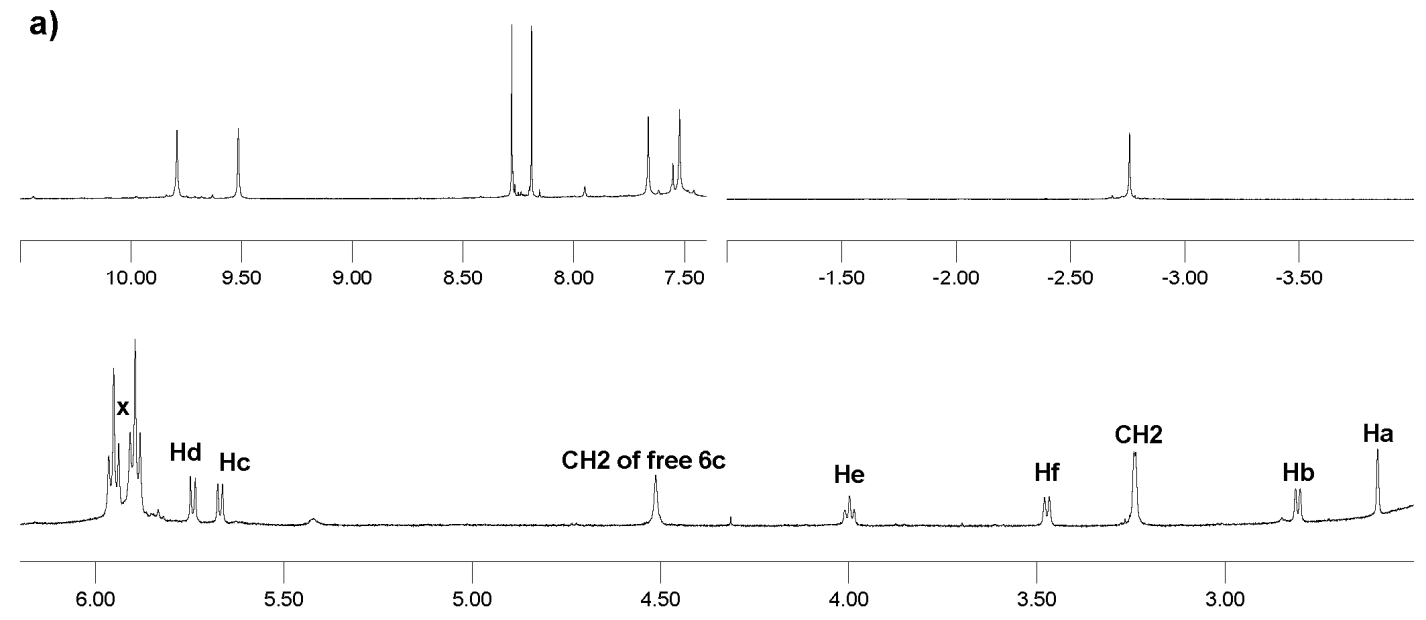

b)

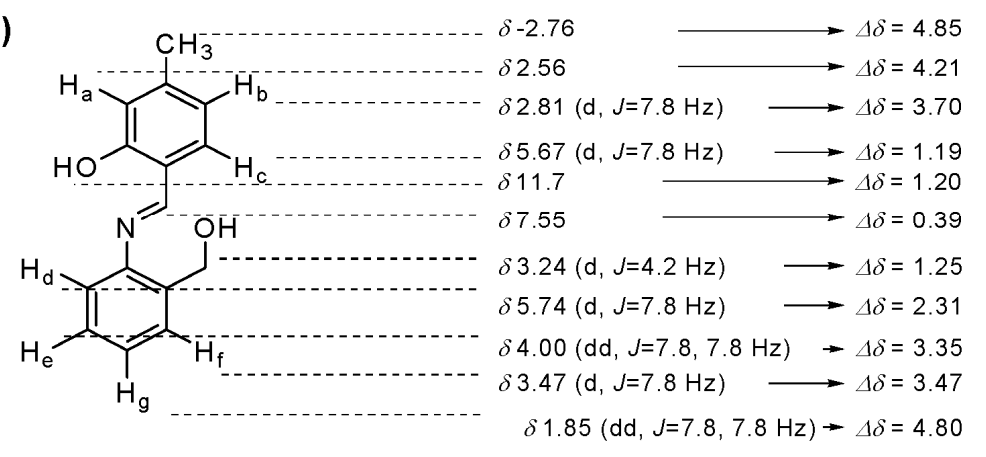

Figure 6S. Encapsulation experiments of 6c. (a) Downfield, mid-field, and upfield portions of ${ }^{1} \mathrm{H}$ NMR spectra (600 MHz, $300 \mathrm{~K}$, mesitylene- $\left.d_{12}\right)$ of $\mathbf{6 c} @ \mathbf{1} \cdot \mathbf{1}$ and free 6c. Downfield portions of ${ }^{1} \mathrm{H}$ NMR; $\delta 9.79$ (s, 4H, NH), 9.52 (s, 4H, NH), 8.28 (s, 4H, arom), 8.19 (s, 4H, arom), 7.95 (s, 1H, N=CH of free 6c), 7.66 (s, 4H, arom), 7.55 (s, 1H, N=CH of 6c@1•1), 7.52 (s, 4H, arom). Other signals in portions of mid-field and upfield are assigned as shown in (b) with $\Delta \delta$ values between free and encapsulated $\mathbf{6 c}$. The peaks labeled $\mathrm{x}$ are $\mathrm{CH}$-methines of $\mathbf{1 \cdot 1}$. 


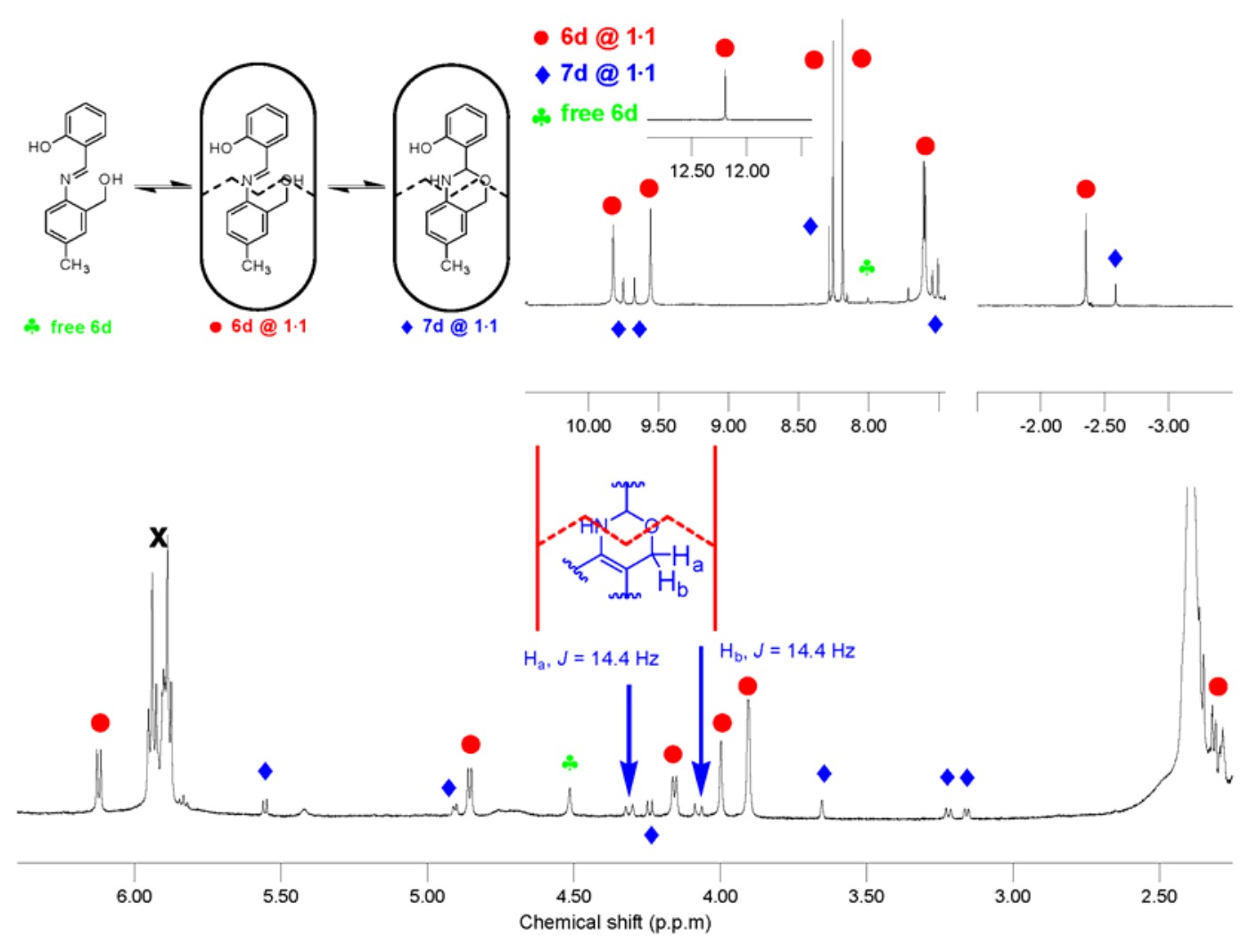

Figure 7S. Encapsulation experiments of 6d. Downfield, mid-field, and upfield portions of ${ }^{1} \mathrm{H}$ NMR spectra (600 MHz, $300 \mathrm{~K}$, mesitylene- $d_{12}$ ) of 6d@1·1 and 7d@1·1.; $\delta$ (for 6d@1·1) 12.2 (s, 1H, OH), 9.82 (s, 4H, NH), 9.56 (s, 4H, NH), 8.25 (s, 4H, arom of 1·1), 8.19 (s, 4H, arom of $\mathbf{1 \cdot 1}), 7.62(\mathrm{~s}, 1 \mathrm{H}, \mathrm{N}=\mathrm{CH}), 7.61$ (s, 4H, arom of $\mathbf{1 \cdot 1}), 7.60(\mathrm{~s}, 4 \mathrm{H}$, arom of 1·1), 6.12 (d, 1H, $J=7.2 \mathrm{~Hz}$ ), 4.85 (d, 1H, $J=7.2 \mathrm{~Hz}$ ), 4.16 (d, 1H, $J=7.2 \mathrm{~Hz}$ ), 4.00 (s, 1H), 3.90 (d, 2H, $J=1.2 \mathrm{~Hz}$ ), $2.32-2.28$ (m, 3H), - 2.35 (s, 3H); $\delta$ (for 7d@1·1) 9.75 (s, 4H, NH), 9.67 (s, 4H, NH), 8.28 (s, 4H, arom of 1.1), 8.19 (s, 4H, arom of $\mathbf{1 \cdot 1}$ ), 7.55 (s, 4H, arom of $\mathbf{1 \cdot 1}), 7.51$ (s, 4H, arom of 1•1), 5.55 (d, $1 \mathrm{H}, J=7.8$ $\mathrm{Hz}$ ), 4.91 (d, 1H, $J=6.0 \mathrm{~Hz}$ ), 4.31 (d, 1H, $J=14.4 \mathrm{~Hz}$ ), 4.24 (d, 1H, $J=9.6 \mathrm{~Hz}$ ), 4.07 (d, $1 \mathrm{H}, J=14.4 \mathrm{~Hz}$ ), 3.65 (s, 1H), 3.22 (d, 1H, $J=9.6 \mathrm{~Hz}$ ), 3.16 (s, 1H, $J=7.8 \mathrm{~Hz}$ ), 2.59 (s, 3H). The ratio of $\mathbf{6 d @ 1 \cdot 1}$ to 7d@1·1 is 87:13 from the integrals of upfield $\mathrm{CH}_{3}$ peaks. The peaks labeled $\mathrm{x}$ are $\mathrm{CH}$-methines of $\mathbf{1 \cdot 1}$. 

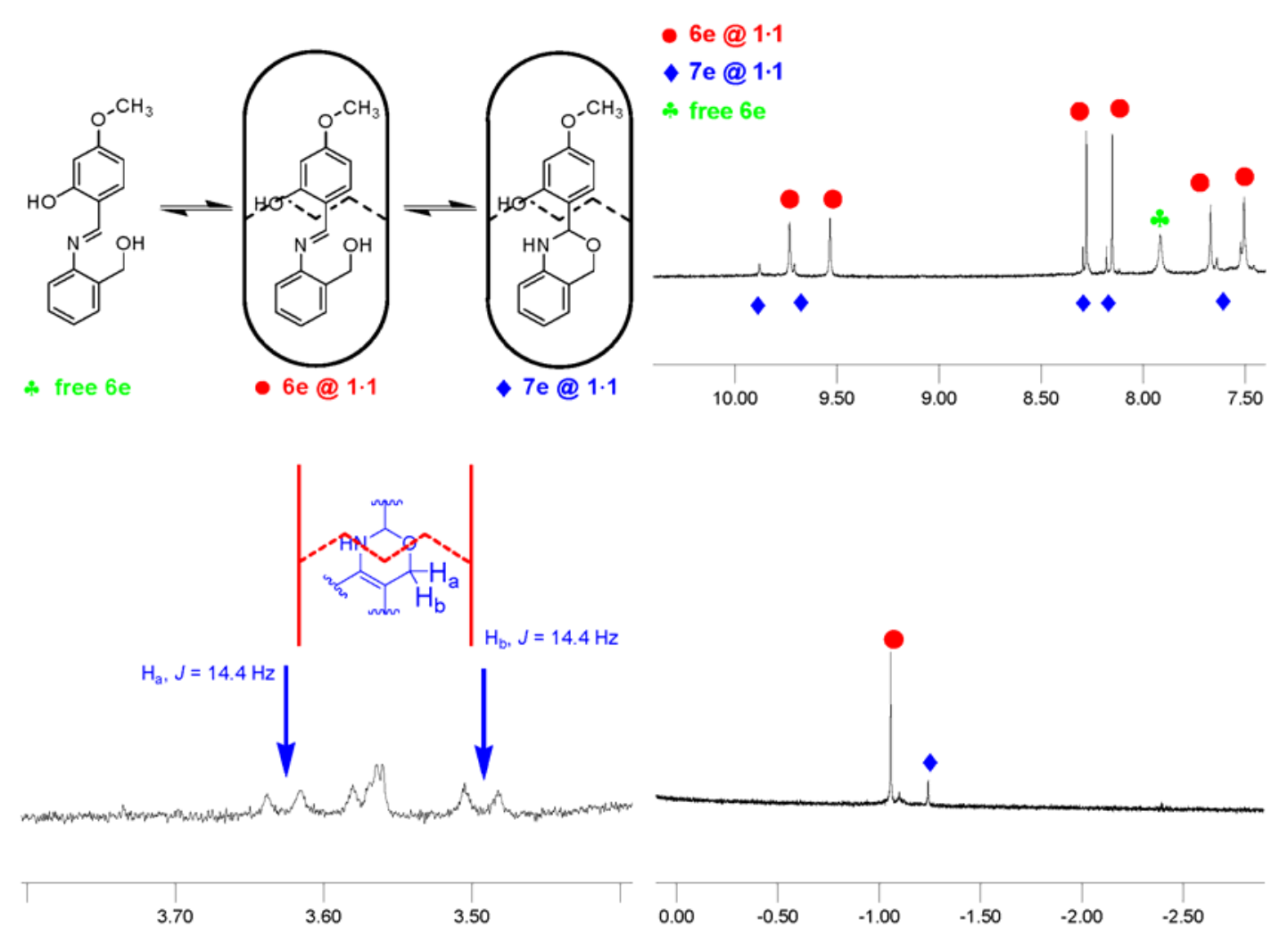

Figure 8S. Encapsulation experiments of 6e. Downfield, mid-field, and upfield portions of ${ }^{1} \mathrm{H}$ NMR spectra (600 MHz, $300 \mathrm{~K}$, mesitylene- $d_{12}$ ) of 6e@1·1 and 7e@1·1.; $\delta$ (for 6e@1.1) 9.73 (s, 4H, NH), 9.53 (s, 4H, NH), 8.28 (s, 4H, arom of 1·1), 8.15 (s, 4H, arom of 1.1), $7.67(\mathrm{~s}, 1 \mathrm{H}, \mathrm{N}=\mathrm{CH}), 7.51$ (s, 4H, arom of 1•1), - $1.06(\mathrm{~s}, 3 \mathrm{H})$; $\delta$ (for 7e@1.1) 9.98 (s, 4H, NH), 9.71 (s, 4H, NH), 8.30 (s, 4H, arom of 1·1), 8.18 (s, 4H, arom of $\mathbf{1 \cdot 1}), 7.64(\mathrm{~s}, 4 \mathrm{H}$, arom of $\mathbf{1 \cdot 1}), 7.52$ (s, 4H, arom of $\mathbf{1 \cdot 1}), 3.62(\mathrm{~d}, 1 \mathrm{H}, J=14.4$ $\mathrm{Hz}$ ), 3.49 (d, $1 \mathrm{H}, J=14.4 \mathrm{~Hz}),-1.24$ (s, 3H). The ratio of $\mathbf{6 e @ 1 \cdot 1}$ to 7e@1·1 is 88:12 from the integrals of upfield $\mathrm{CH}_{3}$ peaks. 


\section{(5) Corroborative data of encapsulation experiments.}

The 8/9 and 10/11 tautomers were prepared and were encapsulated into the host 1•1. The encapsulation phenomena were summarized in Figure 9S. The ${ }^{1} \mathrm{H}$ NMR spectra of encapsulated species were shown in Figure 10S and 11S, as well as the data of free species.

(a)
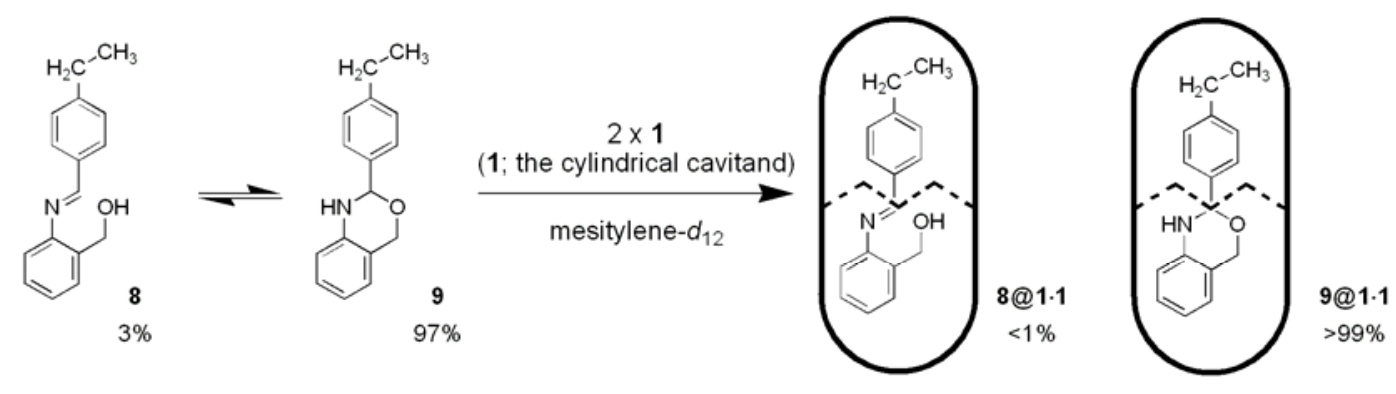

(b)

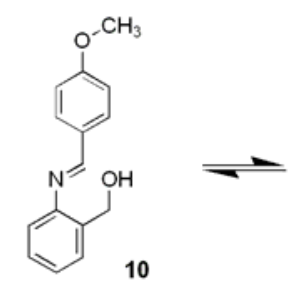

$13 \%$
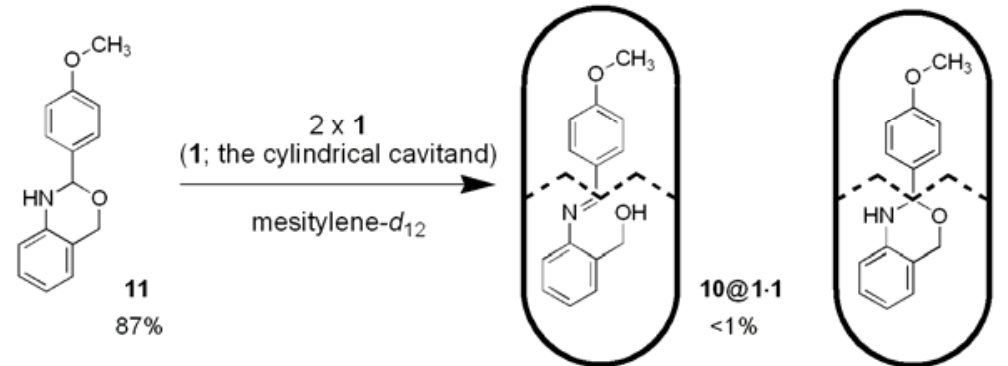

11@1.1 $>99 \%$

Figure 9S. Encapsulation of $\mathbf{8} / \mathbf{9}$ and $\mathbf{1 0} / \mathbf{1 1}$ isomerizations with $\mathbf{1 \cdot 1}$. The experiments were carried out with the guest $\left(2.70 \times 10^{-3} \mathrm{mmol}\right)$ and $\mathbf{1}\left(10 \mathrm{mg}, 5.94 \times 10^{-3} \mathrm{mmol}\right)$ in mesitylene- $d_{12}(1.5 \mathrm{~mL})$; a) a detectable amount of 8@1.1 was not formed; b) a detectable amount of 10@1·1 was not formed. The ratios were determined by ${ }^{1} \mathrm{H}$ NMR (600 MHz, $300 \mathrm{~K}$, mesitylene- $d_{12}$ ). 
a)
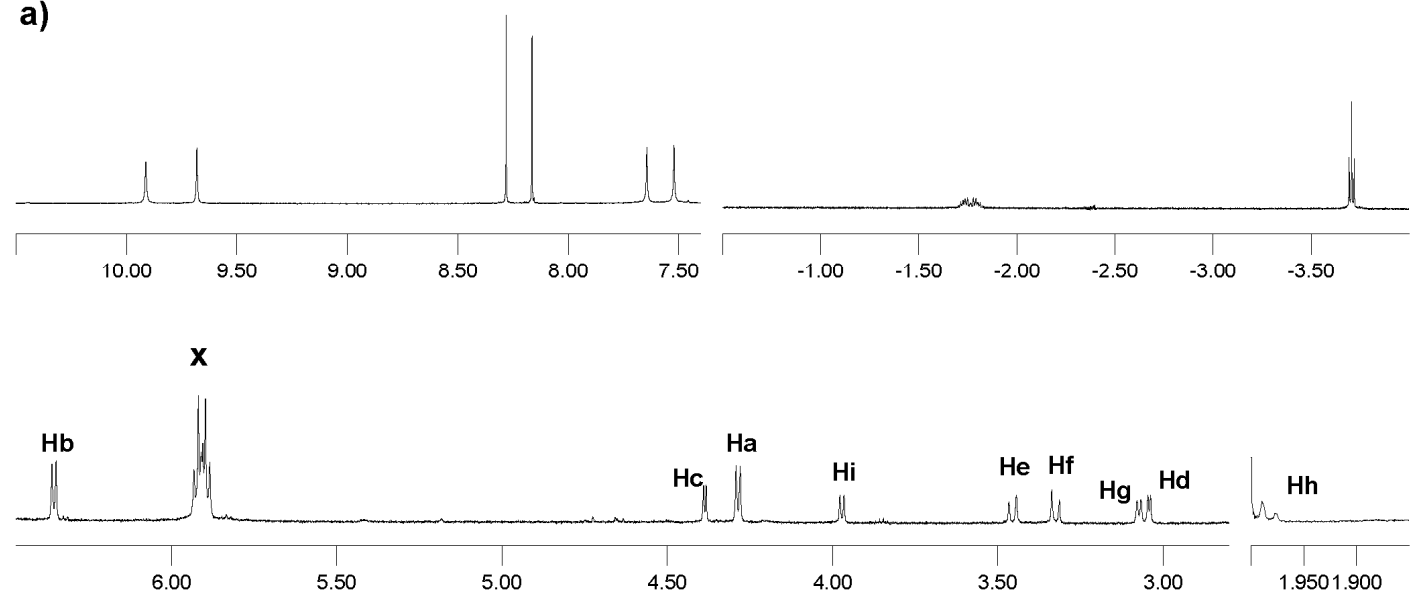

b)

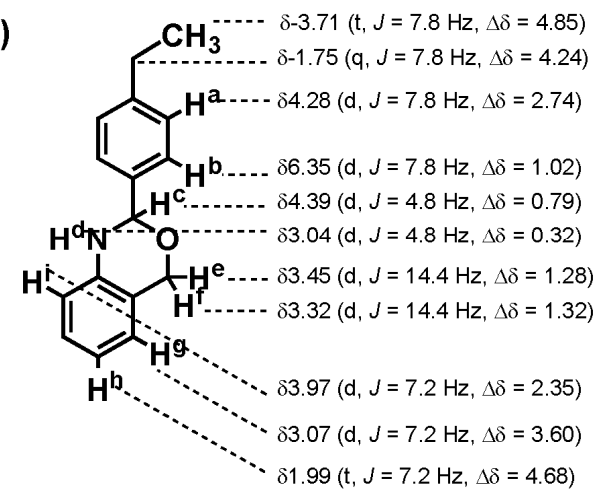

Figure 10S. Encapsulation experiments of 8 and 9. (a) Downfield, mid-field, and upfield portions of ${ }^{1} \mathrm{H}$ NMR spectra (600 MHz, $300 \mathrm{~K}$, mesitylene- $d_{12}$ ) of 9@1·1. A detectable amount of 8@1.1 was not formed. The peaks in downfield portions are corresponding to those of asymmetrically filled capsule, $\delta 9.91$ (s, 4H, NH), 9.68 (s, 4H, NH), $8.28(\mathrm{~s}, 4 \mathrm{H}$, arom), 8.16 (s, 4H, arom), 7.64 (s, 4H, arom), 7.52 (s, 4H, arom). Other signals in portions of mid-field and upfield are assigned as shown in (b) with $\Delta \delta$ values between free and encapsulated 9. The peaks labeled $\mathrm{x}$ are $\mathrm{CH}$-methines of the cylindrical capsule. 
8 and 9: The tautomerism between 8 and 9 in mesitylene- $d_{12}$ plateau with 3:97 ratio. ${ }^{1} \mathrm{H}$ NMR (600 MHz, $300 \mathrm{~K}$, mesitylene- $d_{12}$ ) $\delta$ (for 9) 7.37 (d, $J=8.4 \mathrm{~Hz}, 2 \mathrm{H}$ ), 7.02 (d, $J$ $=8.4 \mathrm{~Hz}, 2 \mathrm{H}), 6.92(\mathrm{dd}, J=8.4 \mathrm{~Hz}, 8.4 \mathrm{~Hz}, 1 \mathrm{H}), 6.67$ (dd, $J=8.4 \mathrm{~Hz}, 8.4 \mathrm{~Hz}, 1 \mathrm{H}), 6.63$ (d, $J=8.4 \mathrm{~Hz}, 1 \mathrm{H}), 6.32$ (d, $J=8.4 \mathrm{~Hz}, 1 \mathrm{H}), 5.18$ (d, $J=6.0 \mathrm{~Hz}, 1 \mathrm{H}), 4.73$ (d, $J=14.4$ $\mathrm{Hz}, 1 \mathrm{H}), 4.64$ (d, $J=14.4 \mathrm{~Hz}, 1 \mathrm{H}), 3.36$ (d, $J=6.0 \mathrm{~Hz}, 1 \mathrm{H}), 2.49$ (q, $J=7.8 \mathrm{~Hz}, 2 \mathrm{H}$ ), 1.14 (t, $J=7.8 \mathrm{~Hz}, 3 \mathrm{H}$ ), $\delta$ (for $\mathbf{8}$, four protons of aryl-ring were overlapped and/or too small, so that could not be accurately assigned.) 7.97 (s, $1 \mathrm{H}$ ), 7.58 (d, $J=8.4 \mathrm{~Hz}, 2 \mathrm{H}$ ), 6.96 (d, $J=8.4 \mathrm{~Hz}, 2 \mathrm{H}), 4.72$ (d, $J=6.0 \mathrm{~Hz}, 1 \mathrm{H}), 3.02$ (d, $J=6.0 \mathrm{~Hz}, 1 \mathrm{H}), 2.44$ (q, $J=$ $7.8 \mathrm{~Hz}, 2 \mathrm{H}), 1.10$ (t, $J=7.8 \mathrm{~Hz}, 3 \mathrm{H}) .{ }^{13} \mathrm{C} \mathrm{NMR}\left(150 \mathrm{MHz}, \mathrm{CDCl}_{3}\right) \delta$ (for 9) 145.2, $141.7,136.5,129.0,128.0,127.3,126.5,124.9,119.6,116.9,85.1,67.7,28.6,15.6, \delta$ (for 8) 159.6, 149.6, 148.7, 135.1, 133.4, 128.5, 128.4, 128.03, 126.3, 122.1, 117.4, 64.0, 28.9, 15.3. HRMS (ESI, $\mathrm{MH}^{+}$): Calcd. For $\mathrm{C}_{16} \mathrm{H}_{18} \mathrm{NO}$ : 240.1383. Found: 240.1385.

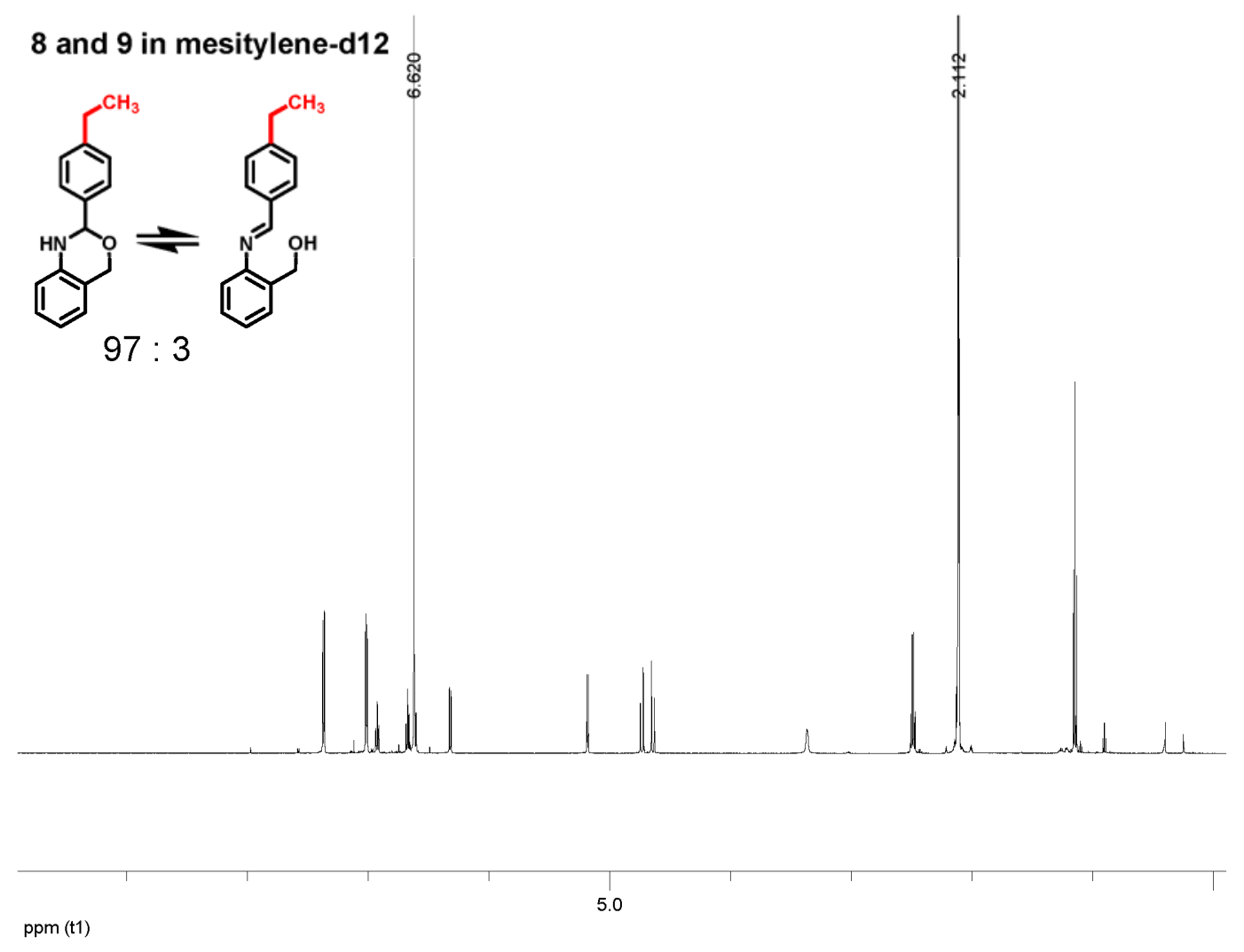


a)

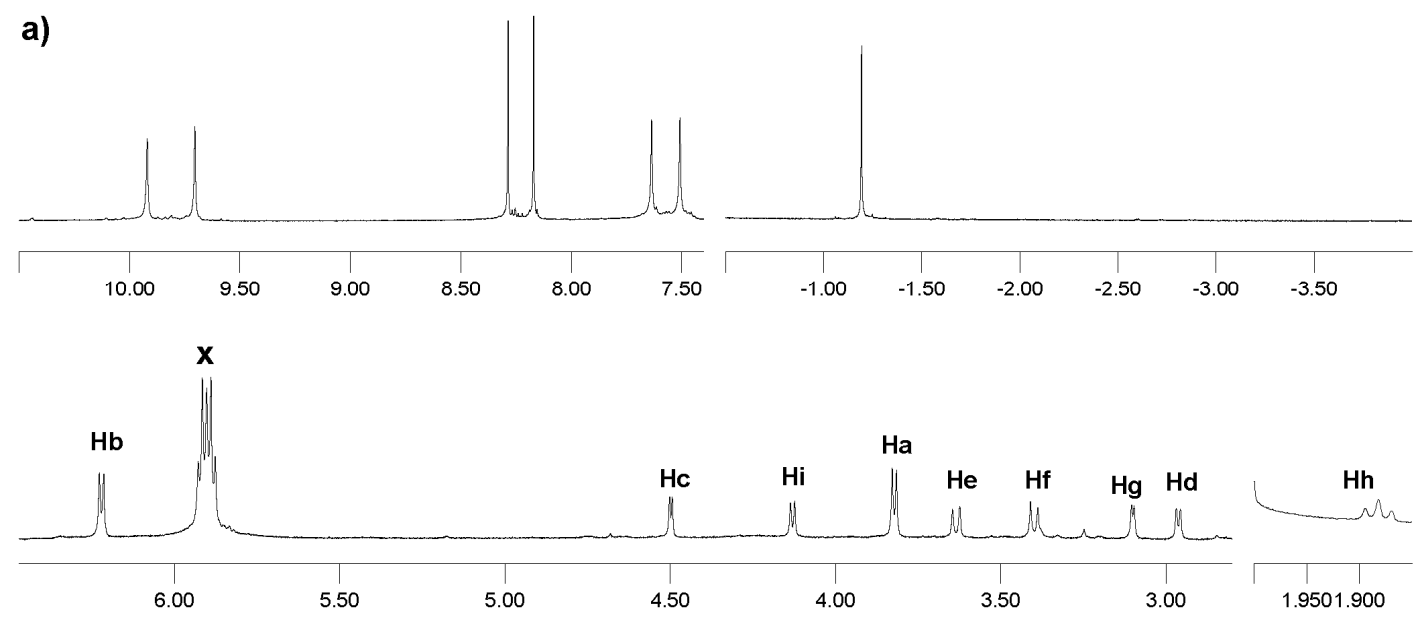

b)

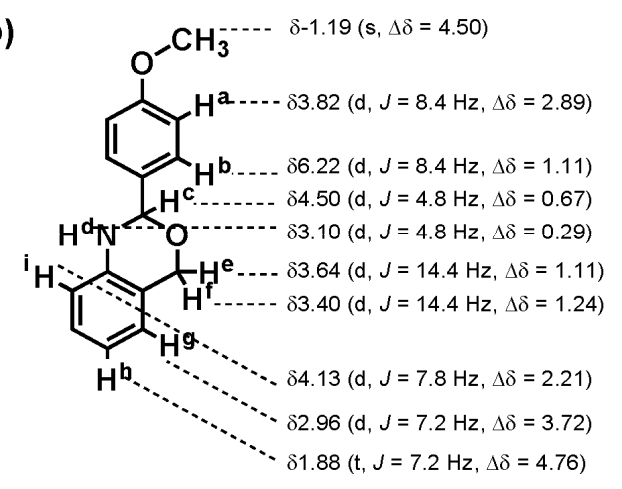

Figure 11S. Encapsulation experiments of 10 and 11. (a) Downfield, mid-field, and upfield portions of ${ }^{1} \mathrm{H}$ NMR spectra (600 MHz, $300 \mathrm{~K}$, mesitylene- $d_{12}$ ) of 11@1·1. A detectable amount of 10@1.1 was not formed. The peaks in downfield portions are corresponding to those of asymmetrically filled capsule, $\delta 9.92$ (s, 4H, NH), $9.70(\mathrm{~s}, 4 \mathrm{H}$, $\mathrm{NH}$ ), 8.21 (s, 4H, arom), 8.17 (s, 4H, arom), 7.64 (s, 4H, arom), 7.51 (s, 4H, arom). Other signals in portions of mid-field and upfield are assigned as shown in (b) with $\Delta \delta$ values between free and encapsulated $\mathbf{1 1}$. The peaks labeled $\mathrm{x}$ are $\mathrm{CH}$-methines of $\mathbf{1 \cdot 1}$. 
$\mathbf{1 0}$ and $\mathbf{1 1}^{3,6}$ : The tautomerism between $\mathbf{1 0}$ and $\mathbf{1 1}$ in mesitylene- $d_{12}$ plateau with 13:87 ratio. ${ }^{1} \mathrm{H}$ NMR (600 MHz, $300 \mathrm{~K}$, mesitylene- $d_{12}$ ) $\delta$ (for 11 ) 7.33 (d, $J=8.4 \mathrm{~Hz}, 2 \mathrm{H}$ ), $6.93(\mathrm{~m}, 1 \mathrm{H}), 6.71(\mathrm{~d}, J=8.4 \mathrm{~Hz}, 2 \mathrm{H}), 6.68(\mathrm{~m}, 1 \mathrm{H}), 6.64(\mathrm{~m}, 1 \mathrm{H}), 6.34$ (d, $J=8.4 \mathrm{~Hz}$, 1H), 5.17 (d, $J=4.8 \mathrm{~Hz}, 1 \mathrm{H}), 4.75$ (d, $J=14.4 \mathrm{~Hz}, 1 \mathrm{H}$ ), 4.64 (d, $J=14.4 \mathrm{~Hz}, 1 \mathrm{H}$ ), 3.39 (d, $J=4.8 \mathrm{~Hz}, 1 \mathrm{H}$ ), 3.37 (s, $3 \mathrm{H}$ ), $\delta$ (for 10 , one proton of aryl-ring was overlapped and/or too small, so that could not be accurately assigned.) 7.95 (s, 1H), 7.56 (d, $J=8.4$ Hz, 2H), 7.12 (m, 1H), 7.08 (m, 1H), 7.00 (d, $J=8.4$ Hz, 1H), 6.75 (d, $J=8.4$ Hz, 2H), 4.74 (brs, 2H), 3.31 (s, 3H), 3.18 (brs, $\left.1 \mathrm{H}),{ }^{13} \mathrm{C} \mathrm{NMR} \mathrm{(150} \mathrm{MHz,} \mathrm{CDCl}_{3}\right) \delta$ (for 11) $160.1,159.0,141.8,131.5,127.8,127.4,124.9,119.6,116.8,113.9,84.9,67.7,55.3, \delta$ (for 10) 162.6, 149.8, 135.0, 130.7, 128.7, 128.5, 128.0, 126.1, 122.0, 117.4, 114.3, 64.2, 55.4. HRMS (ESI, $\mathrm{MH}^{+}$): Calcd. For $\mathrm{C}_{15} \mathrm{H}_{16} \mathrm{NO}_{2}$ : 242.1175. Found: 242.1181.

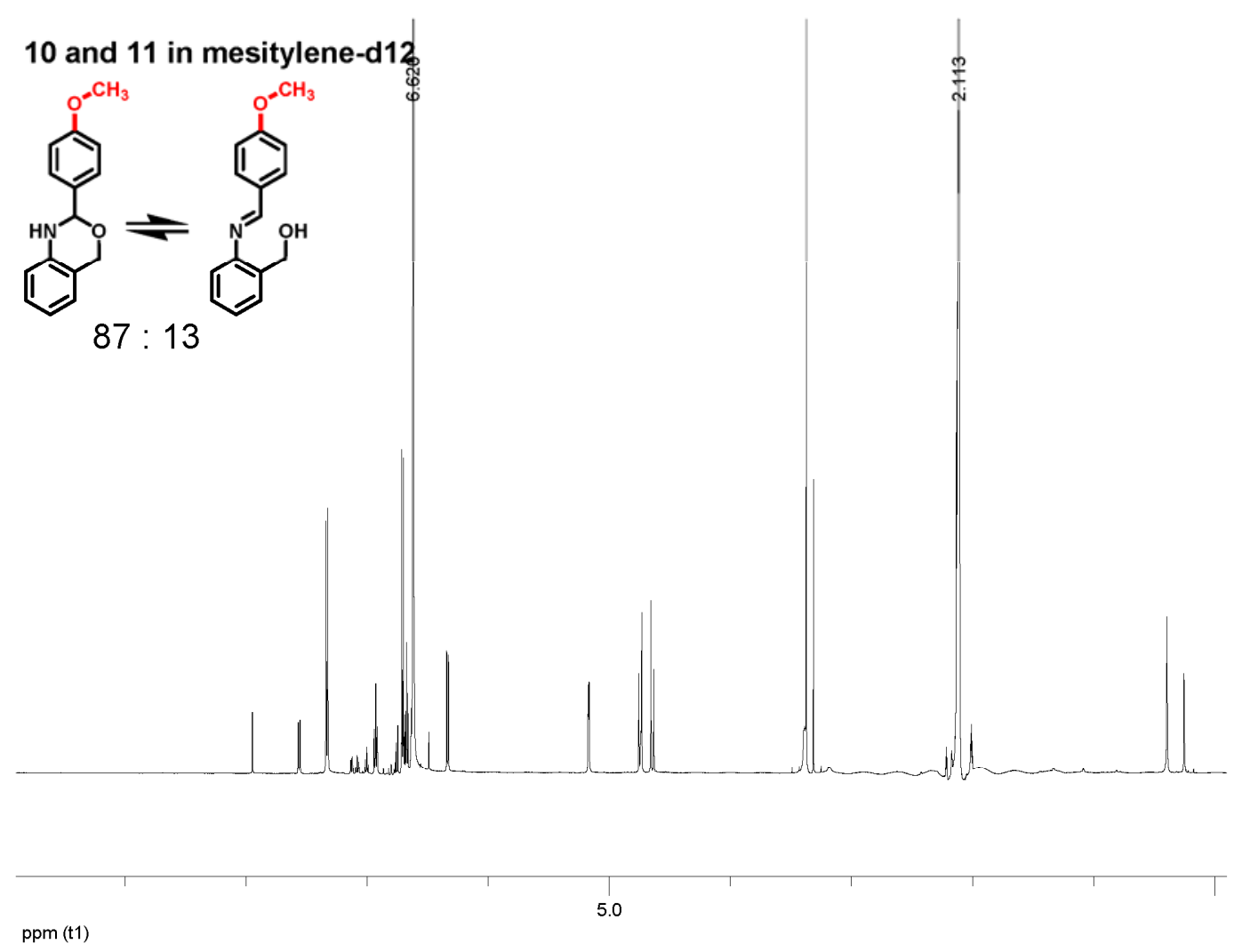




\section{(5) References}

1) Selva, M.; Tundo, P. Perosa, A. J. Org. Chem. 2003, 68, 7374 - 7378.

2) Blaser, D.; Calmes, M.; Daunis, J.; Natt, F.; Tardy-Delassus, A.; Jacquier, R. Org. Prep. Proc. Int. 1993, 25, 338 - 340.

3) Neuvonen, K.; Fülöp, F.; Neuvonen, H.; Koch, A.; Kleinpeter, E.; Pihlaja, K. J. Org. Chem. 2001, 66, $4132-4140$.

4) Koikawa, M.; Yamashita, H.; Tokii, T. Inorg.. Chim. Acta. 2004, 357, 2635 - 2642.

5) Syamal, A.; Singhal, O. P. India. Acta Ciencia Indica, Chemistry 1983, 9, 81 - 88.

6) Alva, A. M. E.; Chokotho, N. C. J.; Jarvis, T. C.; Johnson, C. D.; Lewis, C. C.; McDonnell, P. D. Tetrahedron 1985, 41, 5919 - 5928. 